\title{
Loan Growth and Riskiness of Banks
}

\author{
DANIEL FOOS, LARS NORDEN, MARTIN WEBER*
}

First version: April 30, 2007; this version: December 1, 2007

\begin{abstract}
We investigate whether loan growth affects the riskiness of banks in 14 major western countries under "regular conditions". Using Bankscope data from more than 10,000 individual banks during 1997-2005, we test three hypotheses on the relation between past loan growth and loan losses, bank profitability, and bank solvency. Our empirical evidence supports the view that loan growth leads to a peak in loan loss provisions three years later, to a decrease in relative interest income, and to lower capital ratios. Further analyses reveal that loan growth also has a negative impact on risk-adjusted interest income. These results suggest that loan growth represents an important driver of bank risk.
\end{abstract}

JEL classification: G20, G21

Keywords: bank lending, loan losses, bank profitability, bank solvency

\footnotetext{
* Daniel Foos is Doctoral Student and Research Assistant at the Department of Banking and Finance, University of Mannheim, Email: foos@bank.BWL.uni-mannheim.de. Lars Norden is Assistant Professor at the Department of Banking and Finance, University of Mannheim, and currently visiting the Finance Department, Kelley School of Business, Indiana University, Email: Inorden@indiana.edu. Martin Weber is Professor of Business Adminstration, Banking and Finance at the Department of Banking and Finance, University of Mannheim, and at the Centre for Economic Policy Research (CEPR), Email: weber@bank.BWL.uni-mannheim.de. We wish to thank José Luis Peydró-Alcalde, Wolf Wagner, as well as participants at the $14^{\text {th }}$ Annual Meeting of the German Finance Association Meetings in Dresden, the $2^{\text {nd }}$ Conference on Banking Regulation, Integration and Financial Stability at the Centre for European Economic Research (ZEW) in Mannheim, the research seminar at the University of Mannheim for useful comments and suggestions. In addition, we are grateful to Julia Hein and Jeanette Roth for their support on data issues. Martin Betzwieser provided excellent research assistance.
} 
The activity of lending to customers represents a core function of banks, and is an integral part of the academic literature that explains why banks exist (see Diamond 1984, Bhattacharya and Thakor 1993). Some financial systems have been classified as "bank-based" because most of the funds needed for investment are channeled from households to firms through financial intermediaries (e.g. Levine 2002). Moreover, surveys like the Federal Reserve's Senior Loan Officer Opinion Survey on Bank Lending Practices (SLOS) and the Bank Lending Survey of the European Central Bank have been set up to monitor banks' lending behavior. Given the overall importance of bank lending from a micro- and macroeconomic viewpoint, there are two basic questions to be answered. First, which factors influence loan growth of banks? Second, what are the consequences of loan growth? This paper intends to provide empirical evidence on the second question, analyzing the link between loan growth and riskiness of individual banks. Needless to say that the recent problems in the U.S. subprime mortgage market have raised considerable attention to the link between loan growth and subsequent loan losses.

In addition to macro-economic factors (economic growth, monetary policy, etc.) that matter for all banks there are many bank-specific reasons for an increase or decrease in lending. Either new profitable lending opportunities may arise, like new loan products, lending channels, or lending segments (commercial vs. retail lending, internet-based lending, student loans, etc.), or the expansion to new geographical markets (other regions or countries) occurs. Mechanisms to increase lending are lowering interest rates, loosening credit standards, or both combined. Moreover, a bank may rely on organic internal growth or external growth by means of mergers and acquisitions (M\&A). In any of these cases, it is interesting to study the consequences of loan growth for bank risk, profitability, and solvency. Under the presumption that it is most likely that new loans will be granted to borrowers (i) that have previously been rejected, (ii) that were unknown or non-existent previously, (iii) that demand too low loan rates (too little collateral) relative to their credit quality, loan growth may have 
an adverse impact on the overall risk of a bank. It is trivial to conclude that banks can increase their absolute interest income (and perhaps the absolute net interest result) by an increase of their lending volume, yet it is by far more difficult to assess how loan growth affects relative loan losses, the relative interest income, and the solvency of banks. Furthermore, this issue becomes even more complicated due to the intertemporal nature of the underlying economic relations, as well as bank-specific characteristics.

In this paper, we investigate whether past loan growth affects the riskiness of banks in 14 major western countries under "regular conditions". Using Bankscope data from more than 10,000 individual banks during the period 1997-2005, we test the following three hypotheses (H1-H3), referring to the relation between loan growth and bank risk. Note that we control for bank- and country-specific effects in all analyses. First, we investigate if and how past loan growth affects loan losses. Given the experience that borrowers do not immediately default after they have received a bank loan ("loan seasoning", see Berger and Udell 2004), we expect that loan growth materializes into an increase of loan loss provisions with a time lag of several years (H1). Second, we examine how loan growth influences the profitability of banks. If new loans are granted at a relatively lower rate, the average outstanding loan generates a lower interest income. Accordingly, the relative interest income is expected to decrease (H2). Third, we analyze the impact of loan growth on bank solvency. If banks fund loan growth mainly with new debt, the capital structure becomes more risky. We expect that loan growth leads to an overall decrease of the equity-to-total assets ratio (H3). The multivariate analyses of these hypotheses show that past loan growth is significantly positively related to loan losses and significantly negatively associated with bank profitability and solvency. In other words, loan growth represents an important determinant of the riskiness of banks.

Our paper contributes to the existent literature in several ways. First, most of the related studies have analyzed the aggregate link between business cycles, loan growth, and loan 
losses, focusing on the macro-economic determinants of loan growth. Our paper goes one step further by analzying the consequences of loan growth for the riskiness of individual banks (controlling for macroeconomic variables like GDP growth, inflation, interest rates, etc.). Second, in addition to analyzing the relation between loan growth and loan losses, we also examine the effects on bank profitability and bank solvency to obtain a broader picture of bank risk. Third, we examine the consequences of loan growth under "regular conditions", i.e. we exclude developing countries, emerging markets, and transition economies. Finally, this is the first paper that investigates the effects of loan growth by means of a large international micro-dataset, including important (but relatively different) banking sectors like the U.S. and Germany.

This study relates to the following literature. First, there are theoretical papers explaining changes in the credit policy of banks with reputation, interbank competition, and informational asymmetries (e.g., Rajan 1994, Ogura 2006, Dell'Ariccia and Marquez 2006). Second, related empirical studies based on U.S. data provide evidence that loan growth may lead to a gradual increase of future loan losses (e.g. Sinkey and Greenawalt 1991, Clair 1992, Keeton 1999, Berger and Udell 2004). Sinkey and Greenawalt (1991) analyze large U.S. banks during the period 1984-87 and find that the average past loan growth is significantly positively related to the contemporaneous loan loss rate. Interestingly, they detect a strong variation across banks which cannot be explained by macroeconomic variables. Clair (1992) uses individual bank data from Texas from the period 1976-90 to detect a negative impact of loan growth on nonperforming loans and the loan charge-off rate for the first year after a bank's credit expansion, whereas for subsequent years, a positive relation is partly found. Keeton (1999) investigates the order and timing of potential effects between credit standards, loan growth, and loan losses in the U.S. at the aggregate level. For the period 1982-96, he

\footnotetext{
${ }^{1}$ In this context "regular conditions" refer to a stable economic and legal environment (with banking regulation and moderate macroeconomic cycles) which is typically observed in the countries included in our sample. Accordingly, Japan is excluded because of its relatively long and severe banking crisis.
} 
provides evidence for the view that faster loan growth leads to higher loan losses. Berger and Udell (2004) examine the procyclicality of bank lending in the U.S. during 1980-2000. They find that credit standards are eased and more loans are granted as time passes since a bank's last peak in loan losses. This result is interpreted as evidence in favor of the "institutional memory hypothesis" which claims that a deterioration in the ability of loan officers to recognize potential loan problems may lead to lower credit standards and an increase in lending.

In addition, there is some empirical research on the consequences of loan growth in western European countries as well. For example, Salas and Saurina (2002) analyze a large data set from Spanish commercial and savings banks from the period 1985-1997. Their main discovery is that loan growth (branch growth) of savings banks is significantly positively associated with loan losses three (four) years ahead. Moreover, Quagliariello (2007) investigates the relation between loan growth and loan loss provisioning at Italian banks during the period 1985-2002. He finds that both new bad loans and loan loss provisions are affected by the evolution of the economy. Furthermore, Laeven and Majnoni (2003) have analyzed an international sample of 45 countries from the Bankscope database to examine the determinants of loan loss provisioning and income smoothing of more than 1,000 large banks during the period 1988-1999. It turns out that on average, banks postpone provisioning in favorable cycle conditions until negative conditions set in. This result implies that loan loss provisioning magnifies the impact of economic cycles on banks' income and capital, and should therefore be addressed in bank capital regulation. Iannotta et al. (2007) point out that bank ownership structure is an important determinant of risk and performance, inducing us to carefully control for bank (ownership) types. Finally, there are studies which analyze the relation between loan growth and banking crises in transition economies and developing countries (e.g., see Cottarelli et al. 2005, Kraft and Jankov 2005). 
The remainder of this paper is organized as follows. Section 1 describes the data set and reports summary statistics. Section 2 presents our main results from multivariate tests of the three hypotheses. Section 3 reports findings from further analyses on effects from mergers and acquisitions, differences between weakly and well capitalized banks, and on the riskadjusted income of banks. Results from tests of robustness are reported in Section 4. Section 5 concludes and proposes avenues for future research.

\section{Description of the data}

We analyze yearly balance sheet and income statement data for individual banks in major western countries during the period 1997-2005 stemming from Bankscope. We restrict our sample to banks from the U.S., Canada, and 12 European countries. ${ }^{2}$ The banking systems in these 14 countries, as measured by total banking assets in 2001, are among the 21 largest in the world, and we cover 11 out of the 12 largest banking systems. Furthermore, the sum of GDPs for 11 out of the 14 selected countries adds up to $74 \%$ of the cumulative GDP for the world's 15 largest economies in 2001. Japan, emerging Asian markets, developing countries and transition economies are intentionally excluded from our sample because our goal is to analyze loan growth under "regular conditions". ${ }^{3}$ Lending booms and banking crises in developing countries and transition economies such as China, India or Eastern Europe have been analyzed in other studies. ${ }^{4}$ Since our focus is on bank lending to the private sector, we exclude investment banks, development banks, and other similar institutions. Moreover, the raw data set represents an unbalanced panel, and banks are dropped if the key variables (total loans, changes in loan loss provisions, interest income, and total equity) are not observed in at least five consecutive years. Finally, banks with total assets below 1,000,000 USD are

\footnotetext{
2 Belgium, Denmark, France, Germany, Italy, Luxembourg, the Netherlands, Norway, Spain, Sweden,
} Switzerland, and the United Kingdom.

${ }^{3}$ As Bhattacharya (2003) shows, Bankscope data for emerging economies (e.g. India) has poor quality anyway.

${ }^{4}$ Cottarelli et al. (2005) analyze loan growth in Eastern Europe and the Balkans; Kraft and Jankov (2005) focus on credit growth in Croatia. 
considered as atypical and excluded as well. Table 1 reports the main characteristics of the data set.

Insert Table 1 here

Panel A displays the number of banks remaining in the final data set and compares this to the total number of banks in each country published in OECD statistics. In most of the countries, a substantial fraction of the relevant banks in existence is covered by our data, amounting to an overall coverage of $62.4 \%$. Note that the representativeness measured by the fraction of total assets covered is even higher because Bankscope claims to cover at least $90 \%$ of total banking assets per country.

Panel B summarizes the main variables employed in the subsequent empirical analyses (referring to bank-year observations), as well as macroeconomic control variables (referring to country-year observations). We measure loan growth $\left(\mathrm{LG}_{\mathrm{t}}\right)$ as the percentage change in the amount of total customer loans from the year t-1 to year t. Lending to other financial institutions is not included as this is a distinct line of business that implies a different riskreturn structure. The mean (median) annual loan growth amounts to $11.76 \%(7.93 \%)$. Note that the data set includes some extreme observations from banks which reduced their lending to customers by $37 \%$ during one year as well as banks that expanded total customer loans by $244 \%{ }^{5}$ Loan losses $\left(\mathrm{LL}_{\mathrm{t}}\right)$ are measured as the fraction of the annual change in loan loss provisions established in the year $t$ relative to total customer loans in year $t-1$ (in percentage points). Since borrowers rarely default during the first year after a new loan has been granted, and in order to disentangle losses of longer existing loans from contemporaneous changes in total lending, we prefer this measure to taking total customer loans from year $t$ in the denominator. We are aware of two problems related to this measure of relative loan losses:

\footnotetext{
${ }^{5}$ We address the issue of extreme loan growth in Section 3.1 and Section 4.2 in more detail.
} 
First, loan loss provisions which have been established in one year may be suspended in subsequent years if the borrower recovers from financial distress, which causes a netting effect. Our data does not allow us to control for this effect, i.e. loan losses are systematically underestimated, which creates a conservative bias in our analysis. Second, as the allocation to loan loss reserves reduces the amount of total customer loans in the balance sheet, there may be compensating effects with our measure of loan growth. However, we do not expect any material distortions to be caused by this because changes in loan loss provisions are relatively small (median of $0.36 \%$ ) compared to typical rates of loan growth (median of $7.93 \%$ ).

Initially, all items from the balance sheets and income statements in the Bankscope data base were denominated in U.S. Dollars. To eliminate any distortions caused by currency fluctuations, we calculate loan growth rates as well as loan losses from numbers that were reconverted to the local currency with the appropriate year-specific exchange rate.

The fraction of total interest income over total customer loans represents the relative interest income $\left(\mathrm{RII}_{\mathrm{t}}\right)$. Note that, given that the income statement reflects first-year earnings from lending on a prorated basis, the annual interest income from new loans is likely to be smaller than the annual interest income of loans in the second year and beyond because new loans are granted throughout all calendar months. Therefore, we use the average of total customer loans from year $\mathrm{t}-1$ and year $\mathrm{t}$ as the denominator of $\mathrm{RII}_{\mathrm{t}}{ }^{6}$ The relative interest income, with a median of $9.51 \%$, may be upward biased because of interest-related payments due to guarantees granted that are not part of total customer loans. For this reason, RII exhibits a maximum of $54.63 \%$.

The equity-to-total assets ratio (ETA) represents a typical measure of bank solvency, with values between $2.22 \%$ and $38.52 \%$ and a median of $8.68 \%$. The equity ratio indicates a bank's ability to cover any kind of unexpected losses (due to lending or other activities).

\footnotetext{
${ }^{6}$ Thereby, we employ the total loan volume from year $\mathrm{t}-1$ plus $50 \%$ of the volume of new loans granted during year $\mathrm{t}$, implicitly assuming a uniform distribution of loan granting throughout the year.
} 
Therefore, banks are required to meet a minimum regulatory capital ratio of $8 \%$ under the Basel I and Basel II regimes. In fact, most of the banks hold a considerable capital buffer above the $8 \%$ ratio. Note that we consider values for all variables below the $0.5 \%$-quantile and above the $99.5 \%$-quantile to be outliers, and exclude these observations from all analyses. In the subsequent analyses we control for banks size (using the total amount of customer loans) and differentiate by bank specialization: bank holdings \& holding companies (S_BHHC; 1,376 banks), commercial banks (S_COMM; 6,333 banks), cooperative banks (S_COOP; 1,164 banks), medium \& long term credit banks (S_MLTC; 19 banks), real estate and mortgage banks (S_REMB; 64 banks), and savings banks (S_SAV; 1,272 banks). Finally, we use data from the OECD main economic indicators database to consider macroeconomic effects in each country and year. Specifically, we include the GDP growth rate (GDP_GROW), the inflation rate (INFLAT), the 10-year government bond yield (INT_LONG), and the term premium of interest rates $($ TERM $=$ INT_LONG -3 -month interest rate). All macro variables are scaled in percentage points and described in Panel B of Table 1. GDP growth exhibits a mean of $2.6 \%$ and a maximum value of $8.4 \%$ (Luxembourg, 1999), whereas the highest inflation rate (15.9\%) was observed in Norway (2001). Ten-year government bond yields were on average $4.61 \%$, and values for the term premium range from $-1.82 \%$ to $2.88 \%$. By including these macroeconomic data series, as well as indicator dummy variables for each country, we are able to capture the heterogeneity due to the specific crosscountry composition of our data set.

\section{Empirical analysis}

\subsection{Loan growth and loan losses}

In this section we analyze the impact of past loan growth on contemporaneous loan losses. As stated in H1, we intend to test whether rapid loan growth in the past is associated with a gradual decrease of the average credit quality in a bank's loan portfolio. We start with a 
graphical analysis of relative loan losses (LL1, as defined above) and past loan growth (LG) for the two biggest economies in our sample, as shown in Figure 1.

Insert Figure 1 here

The median of LL1 from all banks in year $t$ in the U.S. (Panel A) and Germany (Panel B) is compared with the median loan growth rate in year t-3. We consider the lag 3 of loan growth because, according to bankers' experience, if borrowers default at all, it would occur at the earliest in the second or third year after the loans have been granted. Panel A displays a clear co-movement of the two variables in the U.S. during the period 2001-2005, indicating that the monotonously decreasing rate of loan growth between 1999 and 2002 may have led to a decline in relative loan loss provisions three years later. Evidence for Germany displayed in Panel B is less clear, but again, a parallel movement of $\mathrm{LL}_{\mathrm{t}}$ and $\mathrm{LG}_{\mathrm{t}-3}$ can be observed during the years 2002-2005. Note that these findings from aggregate numbers might be exclusively driven by business-cycle effects, and that appropriate multivariate econometric models are needed to disentangle banks exhibiting high loan growth rates from moderately growing ones.

In a next step, we continue our analysis with the following regression model:

$$
\begin{aligned}
\text { LOGLL1 }_{t}= & \alpha+\beta_{1} \mathrm{LOGLL}_{t-1}+\sum_{k=1}^{4} \beta_{k+1} \mathrm{LG}_{t-k}+\beta_{6} \mathrm{SIZE}_{t}+\beta_{7} \mathrm{MACRO}_{t}+ \\
& \beta_{8} \mathrm{INT}_{-} \mathrm{LONG}_{t}+\gamma \text { specialization dummies }+\delta \text { country dummies }+\varepsilon
\end{aligned}
$$

First, since almost all values of LL1 are higher than zero, we take the natural logarithm of this variable (LOGLL1), to obtain a $(-\infty,+\infty)$ range of possible values, and thus implicitly exclude net releases of loan loss reserves from our analysis (LL1 $\leq 0 ; 1,711$ observations). As contemporaneous changes in loan loss provisions highly depend on a bank's overall risk characteristics and are accordingly related to past loan losses, we include a lagged dependent 
variable LOGLL1 $1_{\mathrm{t}-1}$. Again, the fact that most of the loan losses typically are not realized before the second year after the loan has been granted ("credit vintage") leads us to include lag 1-4 of loan growth as explanatory variables. If indeed banks expand their total amount of loans by granting credit to lower-quality borrowers, as we expect, we should detect a positive relation between loan losses and past loan growth.

To control for individual bank size $\left(\mathrm{SIZE}_{\mathrm{t}}\right)$, we include the logarithm of its total customer loans $\left(\mathrm{LOGTCL}_{\mathrm{t}}\right)$. The GDP growth rate $\left(\mathrm{GDP}_{-} \mathrm{GROW}_{\mathrm{t}}\right)$ or alternatively the inflation rate $\left(\right.$ INFLAT $\left._{t}\right)$ serve as macroeconomic control variables $\left(\mathrm{MACRO}_{\mathrm{t}}\right)$. Loan losses are expected to increase during economic downturns, i.e. the relation with the GDP growth rate should be negative. A high inflation rate could indicate an economic recession as well; however, up to a certain threshold (which e.g. Khan and Senhadji, 2001, have estimated to range between 1 and 3 percent for industrial countries), inflation is expected not to slow down economic growth. Furthermore, a decrease in the long-term interest rate (INT_LONG $\mathrm{I}_{\mathrm{t}}$ ) lowers the interest expenses and thus reduces a borrower's probability to get into financial distress (and vice versa) - we therefore expect a positive relation with loan losses. To deal with bank specialization- and country-specific effects, we further include indicator dummy variables for each bank type and country, as well as a constant term $\alpha_{i t}$. The models are estimated as OLS regressions with Huber-White robust standard errors, taking into account potential problems from heteroscedasticity and clustering of observations within banks. ${ }^{7}$

Table 2 displays results for changes in loan loss provisions from the baseline regressions. Models (1) and (2) include different macroeconomic control variables. Model (3) drops the lagged dependent variable to confirm its explanatory power.

Insert Table 2 here

\footnotetext{
${ }^{7}$ Robustness tests indicate that all results on H1-H3 are confirmed if we apply fixed-effects and random-effects panel estimators. Additionally, to control for any distortion caused by the intertemporal nature of our regression model (dynamic panel bias), we also consider a dynamic panel estimator (system GMM as proposed by Blundell and Bond 1998) with Windmeijer's (2005) finite sample correction and obtain similar results.
} 
As Hypothesis H1 suggests, we find a substantial, positive, and highly significant impact of $\mathrm{LG}_{\mathrm{t}-2}$ and $\mathrm{LG}_{\mathrm{t}-3}$ on contemporaneous loan losses. In models (1) and (2), the coefficient for $\mathrm{LG}_{\mathrm{t}-4}$ is also significantly positive, but amounts to roughly one third of the coefficient for $\mathrm{LG}_{\mathrm{t}-3}$, which exhibits the strongest effect, as we expected. This result is consistent with the findings of Salas and Saurina (2002), who discover a positive impact of lag 3 of loan growth on total loan loss reserves at Spanish banks. However, since they measure loan losses differently, the magnitude of their results can not be directly compared to our findings. The coefficient for $\mathrm{LG}_{\mathrm{t}-3}$, which is approximately 0.003 in our model (3), means that an increase of loan growth by $20 \%$ (= one standard deviation, starting from the mean of 55 basis points, see Table 1) in year t-3 causes the ratio of relative loan losses to increase by 3.4 basis points to 58.4 basis points. ${ }^{8}$ The effect becomes stronger if we jointly consider loan growth all three previous years (instead of year $\mathrm{t}-3$ only). Note that the negative influence of $\mathrm{LG}_{\mathrm{t}-1}$ is due to a technical effect since $\mathrm{TCL}_{\mathrm{t}-1}$ are included in the numerator of $\mathrm{LG}_{\mathrm{t}-1}$ as well as in the denominator of $\mathrm{LL1}_{\mathrm{t}}$. We cannot detect a significant impact of bank size (measured by LOGTCL $_{t}$ ) on relative loan losses, and the remaining macroeconomic control variables show the expected sign and are highly significant: Higher GDP growth rates and higher inflation have a negative influence on loan losses, which implies that inflation rates were mainly below the aforementioned threshold, whereas an increase in 10-year government bond yields causes loan loss provisions to rise. With respect to bank specialization, our expectation is confirmed that real estate and mortgage banks, which mainly grant secured loans with relatively low default risk, exhibit substantially lower loan losses. This effect is smaller in absolute values, but still significantly negative to the $1 \%$-level, for cooperative and savings banks. ${ }^{9}$

\footnotetext{
${ }^{8}$ Recall that these are average losses on all loans, i.e. they result from previously and newly granted loans.

${ }^{9}$ Using a separate regression model for each bank specialization leads to the same findings regarding the influence of loan growth on loan losses.
} 
Subsequently, we refine our analysis by classifying banks into three categories according to their past loan growth. We distinguish whether the growth rate of a bank's total customer loans in t-3 was below the $33.3 \%$-quantile (lower tercile) in the respective country and year, above the $66.7 \%$-quantile (upper tercile) or in between (mid tercile). We allow banks to move among these categories from year to year. Comparing the median of loan losses, three years after each bank was allocated into one of these groups, we find that relative loan losses of banks from the mid tercile $(0.316 \%)$ are slightly higher those of banks from the lower tercile (0.304\%). Most importantly, banks from the upper growth tercile in t-3 exhibit substantially higher relative loan losses $(0.391 \%)$, which confirms the overall results from Table $2 .{ }^{10}$ To gain deeper insight into the relation between loan losses and past loan growth, we apply the previous regression model to banks in each growth tercile (as defined above). Results are presented in Table $3 .^{11}$

Insert Table 3 here

The expected impact of control variables on $\mathrm{LL} 1_{\mathrm{t}}$ is confirmed for all three categories. In contrast, the impact of past loan growth on contemporaneous loan losses is more differentiated. While the coefficient for $\mathrm{LG}_{\mathrm{t}-2}$ for slowly growing banks is comparable in terms of magnitude to what we observe in the overall regression, loan losses of banks exhibiting moderate past growth are much more sensitive to changes in $\mathrm{LG}_{\mathrm{t}-3}$, resulting in an increase of coefficients by factor 8 , compared to Table 2. For rapidly growing banks which already have high loan loss rates, the sensitivity declines relative to the mid tercile, but remains significantly positive at the $10 \%$-level. One possible explanation for this finding

\footnotetext{
${ }^{10}$ Wilcoxon ranksum tests confirm that all differences in relative loan losses between growth terciles are significantly different from zero at the $1 \%$-level.

${ }^{11}$ Since these groups (terciles) are calculated for different years and due to the unbalanced panel structure of our data, the number of observations or clusters in each category is not exactly the same.
} 
might be that these high loan growth rates are mainly driven by external growth through bank mergers or acquisitions. Note that we reconsider this issue in Section 3.1 in more detail. Another rationale could be that banks increase their lending business to a certain extent by accepting lower-quality borrowers. For further growth, they must rely on other strategies, such as underpricing the competitors' loan rates, to attract borrowers that are not necessarily characterized by a relatively lower creditworthiness.

Summarizing, we find strong support for Hypothesis H1 by discovering a positive and highly significant relation between past loan growth and contemporaneous loan losses at the individual bank-level. In particular, the sensitivity of loan losses to loan growth is highest for banks in the mid growth tercile, meaning that the increase in banks' riskiness due to loan growth is less pronounced for banks exhibiting very low or very high growth rates.

\subsection{Loan growth and interest income}

In this section, we examine whether new loans that have been granted in order to expand a bank's credit portfolio are priced at a lower rate than loans granted by banks aiming to maintain or even reduce their current credit exposure, as suggested by Hypothesis H2. Note that a risk-based loan pricing policy, combined with the positive relation between past loan growth and loan losses detected in Section 2.1, would require banks to charge higher rates for these additional loans compared to the existing credit portfolio. ${ }^{12}$ However, the competition for borrowers may induce banks to underprice the loan rates of competing banks in order to attract new customers (see Ogura 2006).

We use the following regression model to explain the absolute change of the relative gross interest income of each bank $\left(\Delta \mathrm{RII}_{\mathrm{t}}\right)$ by the contemporaneous rate of loan growth $\left(\mathrm{LG}_{t}\right)$ and a set of control variables:

\footnotetext{
${ }^{12}$ We will come back to the impact of loan growth on risk-adjusted interest income in Section 3.3.
} 


$$
\begin{aligned}
\Delta \mathrm{RII}_{\mathrm{t}}= & \alpha_{t}+\beta_{1} \mathrm{LG}_{t}+\beta_{2} \mathrm{SIZE}_{t}+\beta_{3} \mathrm{MACRO}_{t}+\beta_{4} \mathrm{INTEREST}_{t}+ \\
& \gamma \text { specialization dummies }+\delta \text { countrydummies }+\varepsilon
\end{aligned}
$$

The relative interest income in the year $\mathrm{t}\left(\mathrm{RII}_{\mathrm{t}}\right.$ as defined in Section 1) highly depends on $\mathrm{RII}_{\mathrm{t}-1}$ since all rates of loans that have been granted before $\mathrm{t}-1$ and do not mature in the meantime are included in both variables. That is why we take the first difference $\left(\Delta \mathrm{RII}_{t}=\mathrm{RII}_{\mathrm{t}}\right.$ - $\left.\mathrm{RII}_{\mathrm{t}-1}\right)$ to measure the changes in relative interest income, the variable we are actually interested in. Note that $\Delta \mathrm{RII}_{\mathrm{t}}$ only measures the change in average interest income from the entire loan portfolio, i.e. it is impossible to extract the fraction of the interest income that stems from newly granted loans. The contemporaneous loan growth $\left(\mathrm{LG}_{\mathrm{t}}\right)$ represents the main explanatory variable, and according to Hypothesis $\mathrm{H} 2$, we expect the relative interest income to decrease for rapidly growing banks, and thus a negative impact of $\mathrm{LG}_{\mathrm{t}}$ on $\Delta \mathrm{RII}_{\mathrm{t}}$. Again, we control for individual bank size $\left(\mathrm{SIZE}_{\mathrm{t}}\right)$ by including the natural logarithm of its total customer loans $\left(\mathrm{LOGTCL}_{\mathrm{t}}\right)$. As macroeconomic control variables $\left(\mathrm{MACRO}_{\mathrm{t}}\right)$ we include the inflation rate $\left(\right.$ INFLAT $\left._{t}\right)$, or alternatively the GDP growth rate $($ GDP_GROW $)$, which also controls for an economy's credit demand. During economic upturns, the latter is usually higher than in recessions, and banks can then more easily maintain or increase their interest margin than in recessions. The inflation rate should have a positive impact on $\Delta \mathrm{RII}_{\mathrm{t}}$, as banks are required to demand higher nominal loan rates in order to maintain the profitability of their loan portfolio if inflation rates rise. It is essential to control for the long-term interest level (INT_LONG ${ }_{t}$ ), as this variable is expected to be the main macroeconomic driver of interest income and it also stands for aggregate credit supply. Alternatively to INT_LONG the term premium $\mathrm{TERM}_{\mathrm{t}}$, which is expected to be negatively related to $\Delta \mathrm{RII}_{\mathrm{t}}$ since a large difference between long-term and short-term interest rates allows for an increasing maturity transformation by banks, and funding long-term loans by means of short-term deposits facilitates the reduction of loan rates. To deal with bank specialization- and country-specific 
effects, again we include indicator dummy variables for each bank type and country as well as a constant term $\alpha_{i t}$. The models are estimated as OLS regressions with Huber-White robust standard errors, taking into account potential problems from heteroscedasticity and clustering of observations within banks. Table 4 displays regression results for the change in the relative gross interest income.

Insert Table 4 here

We detect a negative and highly significant impact of $\mathrm{LG}_{\mathrm{t}}$ on $\Delta \mathrm{RII}$, which represents evidence in favor of Hypothesis $\mathrm{H} 2$ claiming that loan growth leads to a reduction in relative interest income. For example, the magnitude of the coefficient of approximately -0.005 in models (1) and (2) predicts the relative interest income to decline by $0.15 \%$ if a bank decides to expand its loan portfolio by $30 \%$. The significantly positive coefficient for LOGTCL $_{t}$ indicates that large banks are generally more prone to increase loan rates than smaller banks are. As macroeconomic variables, both GDP_GROW ${ }_{t}$ and INFLAT $_{t}$ exhibit a significantly positive impact on the relative interest income, as expected. Finally, the positive coefficient for INT_LONG $\mathrm{I}_{\mathrm{t}}$ and the negative influence of $\mathrm{TERM}_{\mathrm{t}}$ confirm our predictions about the impact of these variables.

Subsequently, we analyze bank type- and country-specific effects in more detail. For the analyses reported in Table 5, we rely on the model (1) from Table 4. The analysis in Panel A differentiates between bank specializations whereas Panel B provides separate regression results for each of the 14 countries.

Insert Table 5 here 
It turns out that our previous results are mainly confirmed. For commercial banks and savings banks as well as for 8 out of the 14 countries considered, we detect a significantly negative influence of loan growth on loan losses. Interestingly, cooperative banks, with their significantly positive coefficient for $\mathrm{LG}_{\mathrm{t}}$, seem to increase loan rates in a credit expansion. This may be due to the specific ownership and borrower structure of these banks and could also cause the significantly positive relation for Germany, where 734 of 1,332 banks in our sample are credit cooperatives. The coefficients for LOGTCL $L_{t}, I_{N F L A T}$ and INT_LONG show their expected sign with few exceptions. In summary, with the exception of credit cooperatives, our analysis provides clear evidence in favor of Hypothesis H2, i.e. loan growth leads to a decrease in the relative interest income of banks.

\subsection{Loan growth and bank solvency}

Our previous analyses reveal that past loan growth leads to an increase of contemporaneous loan losses and to a decrease of the relative interest income. Taken together, both effects indicate that loan growth increases the riskiness of banks. We now investigate if loan growth leads to an overall decline in bank solvency, as stated in Hypothesis H3. We measure bank solvency by means of the equity-to-total assets ratio for each bank-year observation. ${ }^{13}$

Before turning to the analysis, some additional explanations are in order. Potentially, one might think that it is trivial to assume that loan growth always implies a decline of the equityto-total assets ratio (as stated in Hypothesis H3). However, the following example shows that this is not the case. Consider a bank with outstanding loans of 1,000 and no other assets, which exhibits an equity-to-total assets ratio of $10 \%$, i.e. equity amounts to 100 . Assume that these loans yield, on average, an interest margin of $1 \%$, net of refinancing costs and all other

\footnotetext{
${ }^{13}$ Alternatively, we have measured bank solvency using the equity-to-total customer loans ratio. Note that all results are qualitatively similar to those reported in the remainder of this section.
} 
expenses, with there being no other income or cost types. Thus, during one year, total net earnings add up to 10, and if no dividends are paid (which is not unusual, for example, in case of savings banks), the equity rises to 110 . This corresponds to an increase of the equity-tototal assets ratio from $10 \%$ to $11 \%$. However, this increase in equity allows the bank to extend lending by $10 \%$ to 1,100 during the same year, maintaining the equity-to-total assets ratio at the $10 \%$-level. These alternatives clearly show that loan growth is not necessarily associated with a decrease of the equity-to-total assets ratio. Higher growth rates can similarly be financed by banks with higher net interest margins, other income types (e.g. fee, commission and trading income), or by means of recapitalizations. Therefore, loan growth does not categorically lead to a decline in capital ratios.

We begin with an aggregate analysis of the median of loan growth, calculated across all banks in the U.S. and Germany throughout the period 1998-2005. Figure 2 plots the median of loan growth and the median of changes in the equity-to-total assets ratio (as described in Section 1) from year t-1 to year t. Both Panel A (U.S.) and in particular Panel B (Germany) exhibit an inverse relation between loan growth and bank solvency. Note that since the total amount of loans $\left(\mathrm{TCL}_{\mathrm{t}}\right)$ is also part of the denominator in the equity-to-total assets ratio, there can be some technical relation between these two variables. On the other hand, financing loan growth without additional funds would simply lead to a substitution of assets (e.g. decrease of cash and security holdings, increase of lending) and not cause this technical effect.

Insert Figure 2 here

In the multivariate analysis, we regress absolute changes in the equity-to-total assets ratio of each bank in the year $\mathrm{t}\left(\Delta \mathrm{ETA}_{\mathrm{t}}\right)$ on contemporaneous loan growth and several control variables using the following model: 


$$
\begin{aligned}
\Delta \mathrm{ETA}= & \alpha_{t}+\beta_{1} \mathrm{LG}_{t}+\beta_{2} \mathrm{SIZE}_{t}+\beta_{3} \mathrm{MACRO}_{t}+\beta_{4} \mathrm{INTEREST}_{t}+ \\
& \gamma \text { specialization dummies }+\delta \text { country dummies }+\varepsilon
\end{aligned}
$$

We do not consider the level of the equity-to-total loans ratio as our dependent variable because the technical relation due to loan growth mentioned above would be even higher for this measure of bank solvency. Instead, we calculate the first difference $\Delta \mathrm{ETA}_{\mathrm{t}}=\mathrm{ETA}_{\mathrm{t}}-$ ETA $_{\mathrm{t}-1}$ since capital ratios in subsequent years are usually highly correlated, and we are only interested in the relation between changes in equity and loan growth. The main explanatory variable is the contemporaneous loan growth $\left(\mathrm{LG}_{\mathrm{t}}\right)$. According to Hypothesis $\mathrm{H} 3, \Delta \mathrm{ETA}$ is expected to be negative for banks exhibiting rapid loan growth since these banks may not be able to increase their capital proportionally to the rise in total assets $\left(\mathrm{TA}_{\mathrm{t}}\right)$. We also control for individual bank size $\left(\mathrm{SIZE}_{\mathrm{t}}\right)$ by including the natural logarithm of the amount of total customer loans $\left(\mathrm{LOGTCL}_{\mathrm{t}}\right)$. The GDP growth rate $\left(\mathrm{GDP} \mathrm{GROW}_{\mathrm{t}}\right)$ or alternatively the inflation rate $\left(\right.$ INFLAT $\left._{t}\right)$ serve as macroeconomic control variables $\left(\mathrm{MACRO}_{\mathrm{t}}\right)$. During economic upturns, banks usually realize higher profits that may be retained in order to enhance their capitalization. We therefore expect GDP_GROW $\mathrm{t}_{\mathrm{t}}$ to be positively associated with $\triangle \mathrm{ETA}_{\mathrm{t}}$. Typically, inflation causes prices of balance sheet items to rise, but this does not affect a bank's equity. Due to this effect, the equity-to-total assets ratio is expected to decrease in times of high inflation. Again, as control variables for the interest rate $\left(\right.$ INTEREST $\left._{t}\right)$, we include the 10-year government bond yield (INT_LONG $\left.{ }_{t}\right)$ and the term premium $\left(\mathrm{TERM}_{\mathrm{t}}=\mathrm{INT}_{-} \mathrm{LONG}_{\mathrm{t}}\right.$ minus 3-month interest rate). We deal with bank specialization- and country-specific effects by including indicator dummy variables for each bank type and country as well as a constant term $\alpha_{\mathrm{it} .}$. Finally, the models are estimated as OLS regressions with Huber-White robust standard errors taking into account potential problems from heteroscedasticity and clustering of observations within banks. Table 6 summarizes the regression results for the equity-to-total assets ratio. 
Insert Table 6 here

Most important, with regard to contemporaneous loan growth, we detect a negative impact on $\triangle \mathrm{ETA}_{\mathrm{t}}$, which is at the $1 \%$-level statistically different from zero. In models (1) to (3), the coefficient exhibits a magnitude of approximately -0.025 , meaning that a $30 \%$-expansion of total customer loans causes the equity-to-total assets ratio to decrease by $0.75 \%$. Large banks are more prone to increase their solvency, as the coefficients for LOGTCL $_{t}$ is significantly positive. This may be related to the ownership structure of these large banks, which allows for a higher fraction of profits to be retained. As expected, more favorable economic conditions,

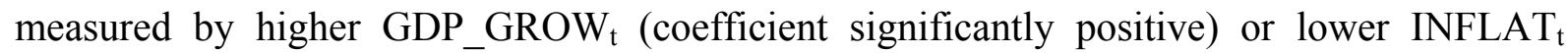
(coefficient significantly negative), lead to an increase in the equity-to-total assets ratio. The 10-year government bond yield exhibits a relatively strong positive impact on bank solvency. As discussed above, this is possibly due to high long term interest rates that allow banks to realize a higher interest income, which they can use to build capital buffers and to increase their equity-to-total assets ratio. The impact of the term premium $\left(\mathrm{TERM}_{\mathrm{t}}\right)$ is statistically significant and negative, but the very small coefficient lacks economic significance.

In addition, we have differentiated the preceding analyses across bank types and countries (details not reported here). Essentially, we find a negative relation of loan growth and bank solvency for all five bank types, with the strongest impact of loan growth on commercial and savings banks' solvency, whereas the effect is weakest again for cooperative banks. This may be caused by a high flexibility for cooperative banks to increase total equity through the admission of new cooperative partners. The analysis on a country level confirms the significantly negative relation between loan growth and the equity-to-total assets ratio, which we already detected for the full sample, for 12 out of 14 countries, which represents clear support in favor of Hypothesis H3. 


\section{Further empirical analyses}

\subsection{Internal versus external growth of banks}

So far, we have not taken into account the reasons for loan growth. On the one hand, a bank may increase the loan volume because of new lending opportunities such as new lending segments or geographic expansion (internal growth). On the other hand, the loan portfolio may increase as a consequence of a takeover or bank merger (external growth). Since the propositions in Hypotheses H1-H3 are implicitly based on the idea of internal growth, we have to control for possible distortions caused by the M\&A activity in the banking industry. Unfortunately, our data does not include bank- and year-specific information on M\&A transactions so that we are unable to directly control for this effect. Instead, we construct an indicator variable MERGE $_{\mathrm{t}}$ that takes the value 1 if a bank's total equity increases by more than $40.0 \%$, which corresponds to the $95 \%$-quantile of the equity growth rate distribution. Otherwise, the value of MERGE $\mathrm{t}_{\mathrm{t}}$ is $0 .{ }^{14}$ After specific accounting operations, the equity of two merging companies is usually pooled ${ }^{15}$, and an increase by more than $40.0 \%$ within one year is very unlikely to result from either retained profits or a regular increase of capital.

In the remainder, we repeat the tests of hypotheses $\mathrm{H} 1-\mathrm{H} 3$ but include the indicator variables MERGE $_{\mathrm{t}}$ (lags 0-4), which we interact with the respective lagged value of loan growth. Estimation results are shown in Table 7.

Insert Table 7 here

\footnotetext{
${ }^{14}$ Alternatively, we define MERGE based on the 95\%-quantile of loan growth and obtain similar results. We also considered a dummy variable that takes a value of 1 if a bank has extreme equity or loan growth in one year (otherwise 0) and sum up this variable over all years for each bank which allows us to distinguish between banks which were involved been involved in M\&A at least once or never. We then re-estimate regression models 1-3 to test H1-H3 for the both sub-samples of banks. This approach leads to results similar to the reported ones.

${ }^{15}$ Likewise, the equity of the acquiring and the acquired company is consolidated.
} 
First, as Panel A displays, the analysis how past loan growth relates to contemporaneous loan losses leads to interesting results. The interaction term $\mathrm{LG}_{\mathrm{t}-1} \mathrm{X}$ MERGE $\mathrm{t}_{\mathrm{t}-1}$ exhibits a significantly negative and large coefficient. Consequently, M\&A activity is predicted to lead to lower loan losses in the short run. The impact of the other lagged interaction terms is less surprising: Coefficients are negative, and summed up with the (positive) coefficients of $\mathrm{LG}_{\mathrm{t}-1}$, $\mathrm{LG}_{\mathrm{t}-2, \ldots}, \ldots$, the net influence of past external loan growth through M\&A activity is significantly weaker than that in the case of internal growth. The overall coefficients of loan growth are -0.0020 for the first lag, 0.0010 for the second, 0.0012 for the third, and -0.0001 for the fourth. Accordingly, there still exists a moderate positive impact which, as we expected, is relatively weak for banks that grew through M\&A. In other words, our previous findings on $\mathrm{H} 1$ are not biased by M\&A transactions in the banking industry.

Second, as stated by H2, the impact of contemporaneous loan growth on relative gross interest income $\left(\Delta \mathrm{RII}_{\mathrm{t}}\right)$ is analyzed in Panel B. Similar to Panel A, we find a strong compensating effect between $\mathrm{LG}_{\mathrm{t}}$ (significantly negative) and $\mathrm{LG}_{\mathrm{t}} \mathrm{X}$ MERGE $\mathrm{t}_{\mathrm{t}}$ (significantly positive), resulting in a net coefficient of 0.0086 . In contrast to the results described in Section 2.2, we now observe a positive effect of loan growth through M\&A on relative interest income, meaning that acquired banks exhibit, on average, higher loan rates than acquirers.

Third, Panel $\mathrm{C}$ reports the corresponding results for the impact of loan growth on bank solvency as stated in Hypothesis H3. We find an almost perfectly compensating effect between $\mathrm{LG}_{\mathrm{t}}$ and $\mathrm{LG}_{\mathrm{t}} \mathrm{X} \mathrm{MERGE}$, meaning there is no impact of external loan growth on bank solvency. We would expect this finding, especially for the case that two equally-well capitalized banks merge, resulting in a proportional increase of equity, total loans, and total assets. In light of these results, we conclude that all of the relations uncovered in previous analyses are downward biased due to banks exhibiting extremely high external growth rates. These persist even when we control for external growth in the manner described above. However, banks relying on external growth strategies through M\&A experience by far weaker 
detrimental consequences regarding loan losses, income and solvency. Most importantly, if we exclude banks involved in M\&A activities, our results for $\mathrm{H} 1-\mathrm{H} 3$ become even stronger.

\subsection{Differentiation by bank capitalization}

The literature as well as banking practice has repeatedly outlined fundamental differences in bank behavior between poorly and well capitalized banks. For example, undercapitalized banks may pursue a strategy like "gambling for resurrection", fostering high growth rates in the short-run, and accepting a potential increase in loan losses in the future. Therefore, we differentiate between weak and strong banks in the following analyses to take a deeper look on the effects regarding all three hypotheses. Banks are classified into three categories according to their equity-to-total assets (ETA) ratio. Observations with an ETA ratio below the $33.3 \%$-quantile (lower tercile - weak banks) in the respective country and year, observations with an ETA ratio above the $66.7 \%$ - quantile (upper tercile - strong banks), and observations exhibiting an ETA ratio in between are analyzed separately. Banks are allowed to move among these categories from year to year.

In Panel A of Table 8, we refine our analysis regarding the effects of past loan growth on contemporaneous loan losses $(\mathrm{H} 1)$ with respect to the three ETA terciles described above. Controlling for macroeconomic, bank-specific, and country effects, Panel A reveals that the positive impact of past loan growth $\left(\mathrm{LG}_{\mathrm{t}-\mathrm{k}}\right)$ on relative loan losses $\left(\mathrm{LOGLL1}_{\mathrm{t}}\right)$ is strongest for weakly capitalized banks while it is considerably less pronounced for better capitalized banks. Panel B reveals significant negative effects of loan growth on relative interest income only for banks in the lower and upper ETA terciles. Undercapitalized banks may rely on an "underpricing" strategy as their poor solvency does not allow for the acceptance of higher-risk borrowers. On the other hand, banks with a high ETA ratio are able to grow by setting low loan spreads, taking advantage of their higher capital buffers that allow a temporary cutback in interest income. Moreover, note that the control variables show the expected sign. Finally, 
Panel $\mathrm{C}$ indicates that a negative relation between loan growth and changes in equity is relatively weak for the lower ETA tercile and increases for better capitalized banks. This is possibly due to regulatory or economic restrictions which do not allow weakly capitalized banks an unlimited further reduction of their anyway poor capitalization.

Insert Table 8 here

An additional explanation for these results may be that strong banks are well-capitalized because they have developed appropriate management skills to obtain a sufficient compensation for risk (loan pricing policy and other lending terms) or to avoid future loan losses (loan exposure and credit portfolio management). Accordingly, the poor capitalization of weak banks may stem from a lacking ability to generate as "healthy" loan growth such as for the case of better capitalized banks. This implies that loan growth is especially dangerous for undercapitalized banks because their capital buffer (which is low anyway) is more sensitive to loan growth. Consequently, monitoring the loan growth of weak institutions may be valuable for banking supervisors.

\subsection{Loan growth and risk-adjusted interest income}

We now complete our analysis of the effects of loan growth on loan losses and interest income with a simultaneous test of Hypotheses $\mathrm{H} 1$ and H2. So far we have analyzed the effects of loan growth on loan losses (Section 2.1) and interest income (Section 2.2) separately. In this section, we intend to analyze whether loan growth also relates to riskadjusted interest income. If this is not the case, loan growth does not represent a potential danger for bank solvency, because risk-adjusted loan pricing and consequent loan monitoring ensure "healthy" loan growth. However, if loan growth is significantly and negatively related to measures of risk-adjusted income, we can conclude that banks are growing by accepting 
lower-quality borrowers, granting loans at rates below the competitive loan rate or both. Note that problems for bank solvency may be most severe in the last case.

We examine the ratio of relative changes in loan loss provisions to relative net interest income $\left(\mathrm{LOGLL1}_{t} / \mathrm{RNII}\right){ }^{16}$ This ratio allows for a joint test of the influence of loan growth on loan losses and interest income. More specifically, we consider two different definitions of the ratio in Model 1 and 2, which differ in the time horizon over which RNII is measured. In Model 1, the ratio is based on lag 3 of the relative net interest income $\left(\mathrm{RNII}_{\mathrm{t}-3}\right)$, because previous findings indicate that loan growth leads to a peak in loan losses three years later. In Model 2, the denominator of the ratio is the average relative net interest income for each bank (ARNII), calculated as the mean of RNII over the four preceding years. Explanatory variables are loan growth (LG), measured over the same time horizon as the dependent variable (Model 1: Lag 3 of loan growth $\mathrm{LG}_{\mathrm{t}-3}$; Model 2: Average loan growth over the four preceding years ALG), the natural logarithm of total customer loans (LOGTCL) to control for bank size, the GDP growth rate, and the 10-year government bond yield (INT_LONG ${ }_{t}$ ) to control for macroeconomic effects, as well as indicator dummy variables for bank specializations and countries.

Insert Table 9 here

It is striking that both $\mathrm{LG}_{\mathrm{t}-3}$ in Model 1 and ALG in Model 2 of Table 9 exhibit highly significant and positive coefficients. These results suggest that higher loan growth leads to an increase of loan loss provisions per unit of net relative interest income. Thus, rapidly growing banks are not able to obtain a sufficient compensation for the additional risks taken. Control variables indicate that in general, larger banks exhibit a more favorable loss-income ratio,

\footnotetext{
${ }^{16}$ Loan loss provisions LOGLL1 $1_{\mathrm{t}}$ are included as natural logarithm and defined as in Section 1 . The relative net interest income (RNII) is calculated by dividing total interest income minus total interest expenses by the average of total customer loans (TCL) in the years $t-1$ and $t$.
} 
which is also the case in times of high inflation. Moreover, note that including the relative net interest income from financial statements in the denominator of the ratio has the advantage that a bank's actual refinancing costs in each year are directly included. However, we are well aware of the problem that due to the time lag between the numerator, denominator, and the measure of loan growth, effects may also partially be driven by changes in refinancing structure or costs.

Therefore, we check the robustness of this finding in a second analysis, using an alternative measure, the risk-adjusted income $\left(\mathrm{RAI}_{\mathrm{t}}\right)$, which is calculated as relative interest income $\left(\mathrm{RII}_{\mathrm{t}}\right)$ minus the 5-year swap rate for each country and year (assumed banks' refinancing costs), processing costs of 0.50 percentage points (assumed value), and the relative loan losses in $\mathrm{t}+3:{ }^{17} \mathrm{RAI}_{t}=\mathrm{RII}_{t}-\mathrm{SWAP} 5_{t}-0.50-\mathrm{LL}_{\mathrm{t}+3}$. The first difference of this variable $\left(\Delta \mathrm{RAI}=\mathrm{RAI}_{t}-\mathrm{RAI}_{\mathrm{t}-1}\right)$ is taken as dependent variable and to be explained by loan growth, controlling for bank size and specialization, macroeconomic effects and countries.

For brevity, regression results are not reported in the paper. We find a negative and highly significant coefficient for $\mathrm{LG}_{\mathrm{t}}$, indicating once again that the risk-adjusted income is likely to decrease at banks exhibiting high loan growth rates. Note that this result is in line with our findings from Table 9, although the dependent variable is very different (Table 9: Level of net returns in the denominator of a ratio; here: First difference of net returns). ${ }^{18}$ As discussed earlier, this finding implies that banks are growing either by granting loans to borrowers that subsequently cause an increase of loan losses, by intentionally setting loan rates below an adequate risk-adjusted level, or both. In summary, these additional tests provide support for the view that loan growth has a negative impact on the risk-adjusted interest income of banks.

\footnotetext{
${ }^{17}$ An alternative risk-adjusted income measure (RAI) based on average loan losses over the years $t+2$ to $t+4$ leads to comparable results.

${ }^{18}$ The variables LOGLL1/RNII and RAI are positively correlated. However, the Spearman rank correlation coefficient is 0.16 , indicating that each of the measures includes a considerable amount of non-redundant information.
} 


\section{Tests of robustness}

\subsection{Two-way linkages between loan growth and loan losses}

In all previous tests of Hypothesis H1, we have examined the one-way relation between past loan growth and contemporaneous loan losses. Subsequently, we study whether our findings remain robust if we explicitly consider intertemporal two-way linkages between loan growth and loan losses. On the one hand, we have shown that loan growth can lead to an increase in future loan losses. On the other hand, banks facing big loan losses may be forced to reduce future loan growth for several reasons (shareholder activism, reputation, accounting policies, risk of bank runs, banking regulation, etc.). For example, Keeton (1999) analyzes aggregate time-series of loan growth and loan losses for the U.S. and finds that there are important two-way linkages. In addition, Berger and Udell (2004) also examine the relation between peaks in loan losses, credit standards and loan growth. Specifically, we estimate a modified two-equation vector autoregressive model (VAR) with the logarithm of changes in contemporaneous loan loss provisions and loan growth as endogenous variables. The righthand side variables (identical in both equations) are the logarithm of the cumulative relative loan losses over the period t-4 to $\mathrm{t}-1$, the cumulative loan growth from $\mathrm{t}-4$ to $\mathrm{t}-1$, a bank size proxy, bank specialization dummies, and country dummies. ${ }^{19}$ Table 10 summarizes the results.

Insert Table 10 here

This analysis yields several interesting results. First and most important, our previous results on the relation between loan growth and future loan losses (Hypothesis H1) remain

\footnotetext{
${ }^{19}$ We have also estimated a VAR model including lags 1, 2, 3, and 4 of loan growth and loan losses and obtain very similar results. However, relative loan loss provisions exhibit strong serial correlation which leads to a multicollinearity problem. As a solution, we consider cumulative variables. Cumulative loan growth is calculated as the product of the annual growth factors minus one (geometric growth) while cumulative relative loan loss provisions are calculated as the sum of the annual loan loss provisions.
} 
robust if we include lags of loan losses. Second, lagged loan losses have indeed a significantly negative impact on contemporaneous loan growth. As discussed above, an increase in loan losses may force a bank to reduce loan growth in the future. Third, it turns out that contemporaneous loan losses can be better explained than contemporaneous loan growth in terms of goodness of fit $\left(\mathrm{R}^{2}\right)$. In other words, the impact of loan growth on future loan losses, as stated in Hypothesis $\mathrm{H} 1$ and analyzed in Section 2.1, is stronger than the inverse relation, underlining the economic relevance of the hypothesis. Finally, as expected, both loan growth and loan losses exhibit positive serial correlation. Summarizing, previous results are confirmed although we find two-linkages (which is consistent with results from studies analyzing aggregate data) between loan growth and loan losses.

\section{2. "Abnormal” loan growth and riskiness of banks}

So far, we have analyzed the consequences of raw loan growth for the riskiness of individual banks. To study the robustness of our previous results, we now define "abnormal" (or "excess") loan growth $\mathrm{LG} 1_{\mathrm{t}}$ as the difference between an individual bank's loan growth in year $t\left(L_{t}\right)$ and the median loan growth of all banks from the same country and year: ALG $G_{t}=$ $\mathrm{LG}_{\mathrm{t}}-\operatorname{med}\left(\mathrm{LG}_{\mathrm{ct}}\right)$. In addition, the variable $\mathrm{DLG}_{\mathrm{t}}$ takes the value of -1 if $\mathrm{LG}_{\mathrm{t}}$ is below the $33.3 \%$-quantile (in the lower tercile) of loan growth for all banks from the same country and year, the value of 1 if is is above the $66.7 \%$-quantile (upper tercile), and the value of 0 if it is mid tercile. The main motivation for using this alternative measure is to zoom in on the part of loan growth that may be caused by bank-specific effects while macro-economic conditions account for the average loan growth in a country and year. In a first step, we compare contemporaneous loan losses for banks that exhibit positive abnormal loan growth for three subsequent years (ALG $>0$ in each of the years) with that of banks that exhibit negative abnormal loan growth in three subsequent years (ALG $<0$ in each of the years). This comparison indicates that loan losses are signficantly higher $(\mathrm{p}$-val. $<0.01)$ at banks which 
grow faster than other banks from the same country and year. In a second step, we carry out multivariate regression analyses to test the hypotheses $\mathrm{H} 1-\mathrm{H} 3$ with our alternative measures of loan growth. Results are summarized in Table 11.

Insert Table 11 here

Most important, it can be seen that the results from our previous analyses of gross loan growth are confirmed for all hypotheses using both new measures of abnormal growth. Interestingly, even the models based on the categorial variable DLG display considerable explanatory power. Second, note that the coefficients for the abnormal loan growth ALG (displayed in regression models (1)) are very similar to those estimated in our previous analyses. We conclude that our baseline results remain robust if we consider two alternative definitions of an individual bank's loan growth. 


\section{Conclusions}

We investigate if and how past loan growth affects the riskiness of banks from 14 major western countries under "regular conditions". Using Bankscope data from more than 10,000 individual banks during 1997-2005, we test three hypotheses to provide evidence on the relation between past loan growth and loan losses, bank profitability, and bank solvency, controling for bank-specific and country-specific effects.

First, with respect to $\mathrm{H} 1$ we find that past loan growth has a positive and highly significant influence on subsequent loan losses with a maximum in the third year. This evidence based on a large international sample of individual banks is consistent with findings from related studies that analyze the aggregate link between loan growth and loan losses in single countries. Second, with respect to $\mathrm{H} 2$, we detect that loan growth also leads to a decline in the relative interest income of banks. This finding holds for most countries and supports the view that new loans which add to the existing credit portfolio tend to be underpriced (relative to the their default risks). Granting loans at rates that do not compensate for default risk may help in fostering loan growth. However, such a strategy decreases the interest income of the average outstanding loan and, in turn, lowers the overall bank profitability ceteris paribus. Third, the test of $\mathrm{H} 3$ reveals that loan growth is significantly negatively related to bank solvency. In 12 out of 14 countries, higher loan growth leads to lower capital ratios, indicating a decrease of bank solvency.

In further analyses, we provide evidence that our baseline results are considerably stronger if we exclude banks involved in M\&A activities. Moreover, the effects of loan growth on loan losses, relative interest income, and bank solvency differ considerably with regard to bank's capitalization. Simultaneous tests of $\mathrm{H} 1$ and $\mathrm{H} 2$ yield that loan growth leads to a deterioration in a bank's risk-return structure. Finally, although we find intertemporal two-way linkages between loan growth and loan losses, the aforementioned positive relation between past loan growth and contemporaneous loan losses remains robust and turns out to be economically 
more important than the inverse relation. In another robustness test, we consider abnormal loan growth instead of raw loan growth and obtain highly similar results.

This paper has several implications. First, bank managers should check whether the additional income from loan growth represents an adequate compensation for the additional risk taking. Second, banking supervisors can monitor loan growth in order to get early warning signals about the riskiness of individual banks (e.g., Curry, Fissel, and Ramirez 2006). Further research may take a broader perspective in analyzing the effects of bank growth on bank risk, distinguishing between an increase of on-balance sheet activities (interest income) and a shift to off-balance sheet activities (non-interested income). Finally, it would be interesting to investigate whether credit ratings and market-based credit risk indicators like stock prices and credit spreads (from bond and credit derivatives markets, see e.g. Lown and Morgan 2006) of large banks are complementary to accounting-based, dynamic bank activity measures like loan growth. 


\section{Literature Cited}

Berger, Allen N., and Gregory F. Udell. (2004). "The institutional memory hypothesis and the procyclicality of bank lending behavior." Journal of Financial Intermediation 13, 458-495.

Bhattacharya, Kaushik. (2003). "How good is the BankScope database? A cross-validation exercise with correction factors for market concentration measures.” BIS Working Paper No. 133, Bank for International Settlements, September 2003.

Bhattacharya, Sudipto, and Anjan V. Thakor. (1993). "Contemporary banking theory." Journal of Financial Intermediation 3, 2-50.

Blundell, Richard, and Stephen Bond. (1998). "Initial conditions and moment restrictions in dynamic panel data models.” Journal of Econometrics 87, 115-143.

Clair, Robert T. (1992). "Loan Growth and Loan Quality: Some Preliminary Evidence from Texas Banks.” Federal Reserve Bank of Dallas Economic Review, $3^{\text {rd }}$ quarter 1992, 9-22.

Cottarelli, Carlo, Giovanni Dell'Ariccia, and Ivanna Vladkova-Hollar. (2005). "Early birds, late risers, and sleeping beauties: Bank credit growth to the private sector in Central and Eastern Europe and in the Balkans.” Journal of Banking and Finance 29, 83-104.

Curry, Timothy J., Gary S. Fissel, and Carlos D. Ramirez. (2006). “The Effect of Bank Supervision on Loan Growth.” Working Paper, September 2006.

Dell'Arriccia, Giovanni, and Robert Marquez. (2006). "Lending booms and lending standards.” Journal of Finance 61, 2511-2546.

Diamond, Douglas W. (1984). "Financial intermediation and delegated monitoring." Review of Economic Studies 51, 393-414.

Iannotta, Giuliano, Giacomo Nocera, and Andrea Sironi. (2007). “Ownership structure, risk and performance in the European banking industry." Journal of Banking and Finance 31, 2127-2149.

Keeton, William R. (1999). “Does faster loan growth lead to higher loan losses?” Federal Reserve Bank of Kansas City Economic Review, $2^{\text {nd }}$ quarter 1999, 57-75. 
Khan, Mohsin S., and Abdelhak S. Senhadji. (2001). "Threshold Effects in the Relationship Between Inflation and Growth.” IMF Staff Papers 48, No. 1.

Kraft, Evan, and Ljubinko Jankov. (2005). "Does speed kill? Lending booms and their consequences in Croatia.” Journal of Banking and Finance 29, 105-121.

Laeven, Luc, and Giovanni Majnoni. (2003). "Loan loss provisioning and economic slowdowns: too much, too late?" Journal of Financial Intermediation 12, 178-197.

Levine, Ross. (2002). "Bank-Based or Market-Based Financial Systems: Which is better?" Journal of Financial Intermediation 11, 398-428.

Lown, Cara, Morgan, Donald P. (2006). "The credit cycle and the business cycle: new findings using the loan officer opinion survey." Journal of Money, Credit, and Banking $38,1575-1597$.

Ogura, Yoshiaki. (2006). "Learning from a rival bank and lending boom." Journal of Financial Intermediation 15, 535-555.

Quagliariello, Mario. (2007). “Banks' riskiness over the business cycle: a panel analysis on Italian intermediaries.” Applied Financial Economics 17, 119-138.

Rajan, Raghuram G. (1994). "Why Bank Credit Policies Fluctuate: A Theory and Some Evidence.” Quarterly Journal of Economics 109, 399-441.

Salas, Vicente, and Jesús Saurina. (2002). "Credit Risk in Two Institutional Regimes: Spanish Commercial and Savings Banks.” Journal of Financial Services Research 22, 203-224.

Sinkey, Joseph F., and Mary Brady Greenawalt. (1991). "Loan-Loss Experience and RiskTaking Behavior at Large Commercial Banks.” Journal of Financial Services Research 5, 43-59.

Windmeijer, Frank. (2005). "A finite sample correction for the variance of linear efficient two-step GMM estimators.” Journal of Econometrics 126, 25-51. 
Figure 1

Contemporaneous loan losses and past loan growth

Panel A: U.S.

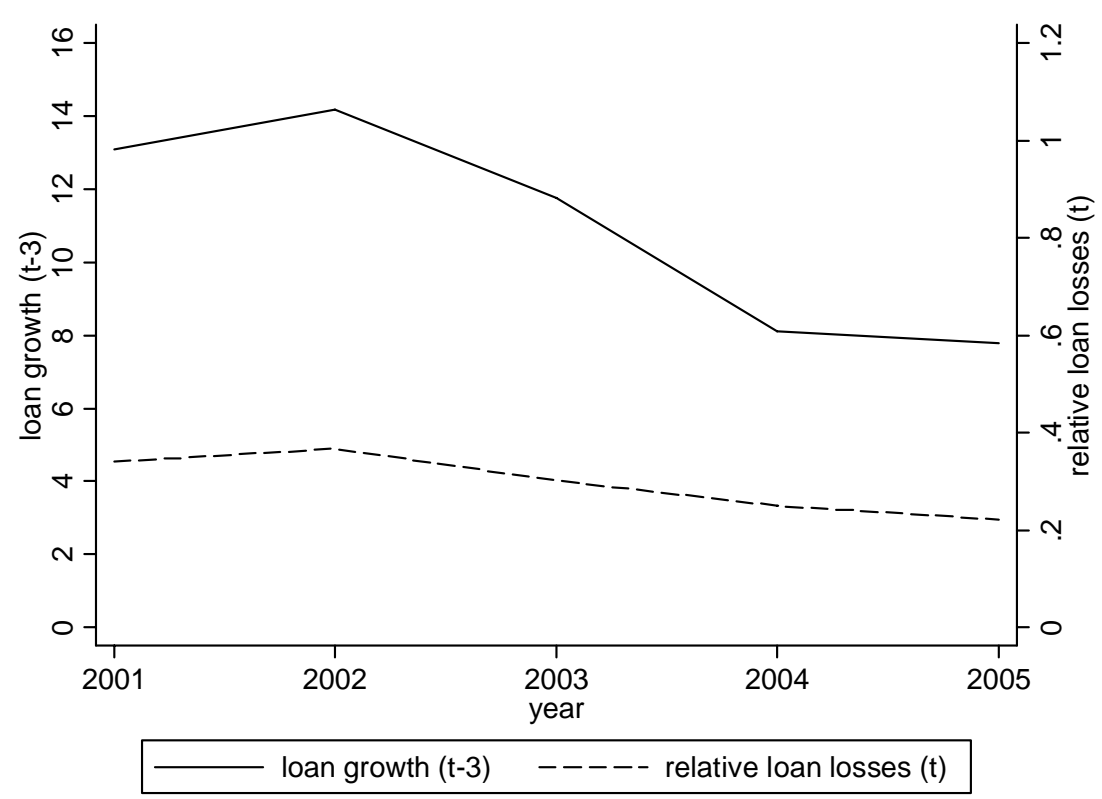

Panel B: Germany

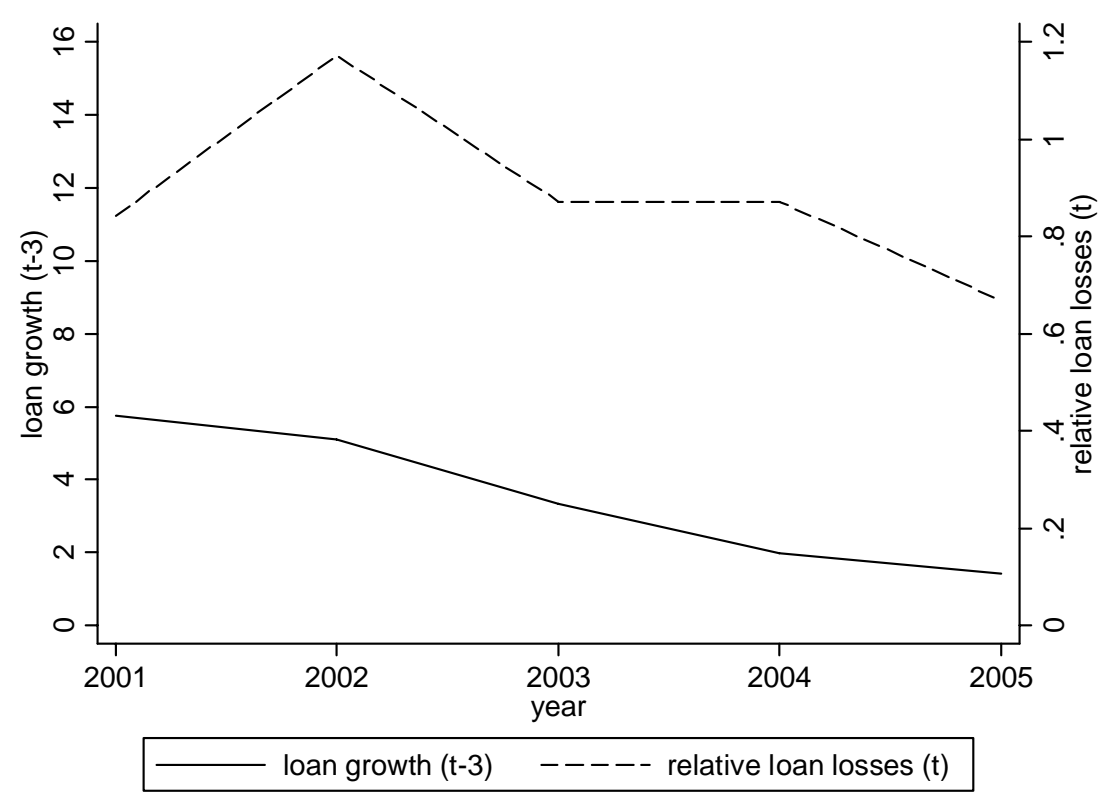

Notes: These graphs display the median of loan growth in the year $\mathrm{t}-3$ and the median of relative loan losses, defined as the fraction of changes in total loan loss provisions in $t$ over the total amount of customer loans in $\mathrm{t}-1$, in percentage points. Values across all banks in the U.S. and in Germany are presented in panel A and B. Loan growth is scaled on the left axis; relative loan losses are scaled on the right axis. 
Figure 2

Loan growth and the equity-to-total assets ratio over the business cycle

Panel A: U.S.

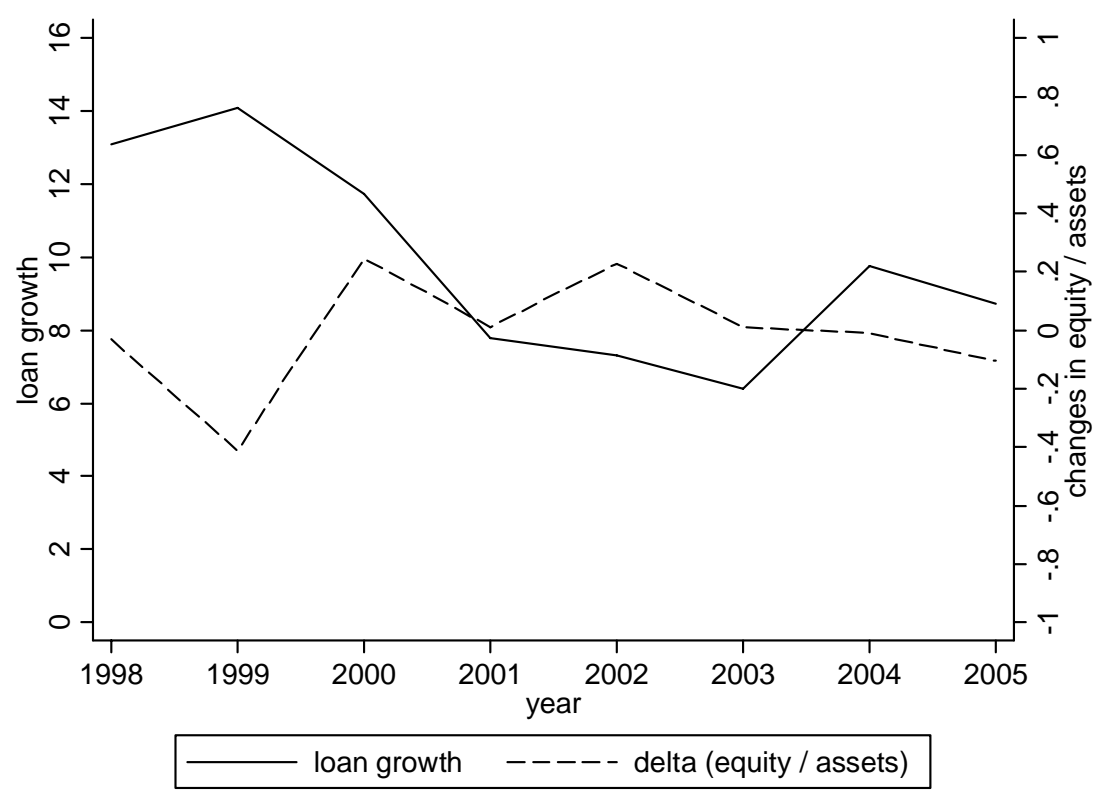

Panel B: Germany

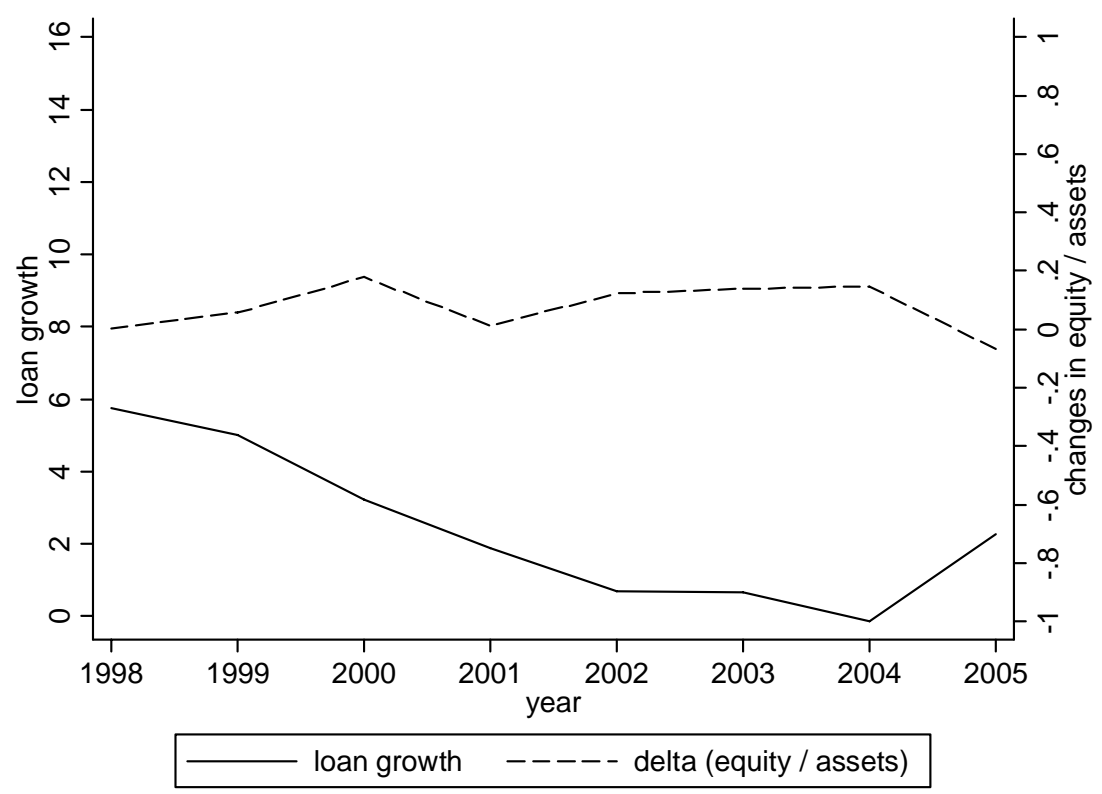

Notes: These graphs display the median of loan growth, and the median of changes from $t-1$ to $t$ in the equity-tototal assets ratio of a bank in percentage points. Values across all banks in the U.S. and in Germany are presented in panel A and B. Loan growth is scaled on the left axis; the changes in the equity-to-total assets ratio are scaled on the right axis. 
Table 1

\section{Summary statistics}

Panel A: Bankscope and OECD statistics (2001)

\begin{tabular}{lrrr}
\hline Country & $\begin{array}{c}\text { No. of banks } \\
\text { in data set }\end{array}$ & $\begin{array}{c}\text { No. of banks } \\
\text { (OECD) }\end{array}$ & $\begin{array}{c}\text { Fraction of banks } \\
\text { covered in data set }\end{array}$ \\
\hline Belgium & 29 & 118 & $24.6 \%$ \\
Canada & 30 & 48 & $64.6 \%$ \\
Denmark & 73 & 117 & $62.4 \%$ \\
France & 203 & 507 & $40.0 \%$ \\
Germany & 1,332 & 2,434 & $54.7 \%$ \\
Italy & 467 & 830 & $56.3 \%$ \\
Luxembourg & 21 & 189 & $11.1 \%$ \\
Netherlands & 17 & 93 & $18.3 \%$ \\
Norway & 26 & 152 & $17.1 \%$ \\
Spain & 87 & 281 & $31.0 \%$ \\
Sweden & 22 & 126 & $17.5 \%$ \\
Switzerland & 41 & 350 & $11.7 \%$ \\
United Kingdom & 71 & 385 & $18.4 \%$ \\
United States & 7,809 & 8,129 & $96.1 \%$ \\
\hline Total & 10,228 & 16,397 & $62.4 \%$ \\
\hline
\end{tabular}

Panel B: Descriptive statistics of main variables

\begin{tabular}{|c|c|c|c|c|c|c|c|}
\hline Variable & Notation & No. of obs & Mean & Median & St. dev. & Min & Max \\
\hline Relative loan losses (in \%) & LL1 & 60,135 & 0.55 & 0.36 & 0.67 & -1.02 & 8.68 \\
\hline Loan growth (in \%) & LG & 60,135 & 11.76 & 7.93 & 20.42 & -36.95 & 243.76 \\
\hline Relative interest income (in \%) & RII & 60,135 & 10.11 & 9.51 & 3.24 & 4.03 & 54.63 \\
\hline Equity-to-total assets (in \%) & ETA & 70,278 & 9.17 & 8.68 & 3.56 & 2.22 & 38.52 \\
\hline Total assets (in bill. USD) & TA & 70,278 & 3.62 & 0.22 & 34.42 & 0.0041 & $1,565.65$ \\
\hline Total customer Loans (in bill. USD) & $\mathrm{TCL}$ & 70,278 & 1.96 & 0.15 & 15.82 & 0.0016 & 675.51 \\
\hline GDP growth rate (in \%) & GDP_GROW & 70,278 & 2.60 & 2.5 & 1.34 & -0.2 & 8.4 \\
\hline Inflation rate (in \%) & INFLAT & 70,278 & 1.99 & 2.1 & 0.87 & -1.9 & 15.9 \\
\hline 10 -year government bond yield (in \%) & INT_LONG & 70,278 & 4.86 & 4.61 & 0.7 & 2.1 & 7.05 \\
\hline Term premium of interest rates (in \%) & TERM & 70,278 & 1.49 & 1.33 & 1.15 & -1.82 & 2.88 \\
\hline
\end{tabular}


Table 2

Regression results for changes in loan loss provisions

\begin{tabular}{|c|c|c|c|c|c|c|c|c|c|}
\hline \multirow{2}{*}{$\begin{array}{l}\text { Dep. Var.: LOGLL1 } 1_{t} \\
\text { Explanatory Var. }\end{array}$} & \multicolumn{3}{|c|}{$(1)$} & \multicolumn{3}{|c|}{$(2)$} & \multicolumn{3}{|c|}{ (3) } \\
\hline & Coeff. & & p-val. & Coeff. & & p-val. & Coeff. & & p-val. \\
\hline LOGLL $_{t-1}$ & 0.601375 & $* * *$ & 0.000 & 0.597702 & $* * *$ & 0.000 & & & \\
\hline $\mathrm{LG}_{\mathrm{t}-1}$ & -0.000615 & & 0.133 & -0.000248 & & 0.553 & 0.000248 & & 0.602 \\
\hline $\mathrm{LG}_{\mathrm{t}-2}$ & 0.001364 & $* * *$ & 0.000 & 0.001283 & $* * *$ & 0.001 & 0.002452 & $* * *$ & 0.000 \\
\hline $\mathrm{LG}_{\mathrm{t}-3}$ & 0.001888 & $* * *$ & 0.000 & 0.001917 & $* * *$ & 0.000 & 0.003005 & $* * *$ & 0.000 \\
\hline $\mathrm{LG}_{\mathrm{t}-4}$ & 0.000629 & $* *$ & 0.013 & 0.000544 & $* *$ & 0.032 & 0.002699 & $* * *$ & 0.000 \\
\hline LOGTCL $_{t}$ & 0.002606 & & 0.576 & -0.002259 & & 0.635 & 0.015767 & $*$ & 0.061 \\
\hline GDP_GROW $_{\mathrm{t}}$ & -0.061806 & $* * *$ & 0.000 & & & & -0.126000 & $* * *$ & 0.000 \\
\hline $\mathrm{INFLAT}_{\mathrm{t}}$ & & & & -0.164180 & $* * *$ & 0.000 & & & \\
\hline INT_LONG & 0.325026 & $* * *$ & 0.000 & 0.405538 & $* * *$ & 0.000 & 0.230798 & $* * *$ & 0.000 \\
\hline S_B & -0.000932 & & 0.958 & -0.003728 & & 0.833 & 0.011456 & & 0.698 \\
\hline S_COOP & -0.200554 & $* * *$ & 0.000 & -0.208628 & $* * *$ & 0.000 & -0.456961 & $* * *$ & 0.000 \\
\hline S_MLTC & -0.108000 & & 0.411 & -0.115466 & & 0.375 & -0.531656 & $* *$ & 0.045 \\
\hline S_REMB & -0.802929 & $* * *$ & 0.000 & -0.789404 & $* * *$ & 0.000 & -2.016473 & $* * *$ & 0.000 \\
\hline S_SAV & -0.150205 & $* * *$ & 0.000 & -0.153600 & $* * *$ & 0.000 & -0.459563 & $* * *$ & 0.000 \\
\hline+- country dummies & & & & & & & & & \\
\hline Constant & -3.764025 & $* * *$ & 0.000 & -3.880508 & $* * *$ & 0.000 & -6.677734 & $* * *$ & 0.000 \\
\hline No. of obs. & 18,283 & & & 18,283 & & & 18,585 & & \\
\hline No. of clusters & 8,718 & & & 8,718 & & & 8,863 & & \\
\hline Adj. $R^{2}$ & 0.515 & & & 0.516 & & & 0.273 & & \\
\hline
\end{tabular}

Notes: The dependent variable is the natural logarithm of the ratio of loan losses in t (LOGLL1), defined as the fraction of the changes in total loan loss provisions in $t$ over the total amount of customer loans in $t-1$. Explanatory variables are the lags 1-4 of loan growth (LG), and in models (1) and (2) the lagged dependent variable. We control for bank-specific effects using the logarithm of total customer loans (LOGTCL), and indicator dummy variables for each bank specialization: Commercial banks form the reference group, whereas Bank Holdings \& Holding Companies are denoted by S_BHHC $=1$, Cooperative Banks by S_COOP=1, Medium \& Long Term Credit Banks by S_MLTC=1, Real Estate / Mortgage Banks by S_REMB=1 and Savings Banks by $\mathrm{S}$ _SAV=1. As macroeconomic control variables, the GDP growth rate (GDP_GROW), the inflation rate (INFLAT) and the 10-year government bond yield (INT_LONG) are included, as well as country dummies. Pvalues are calculated from Huber-White robust standard errors, controlling for clustering at individual banks. $* * *, * *, *$ indicate that coefficients are statistically significant at the $1 \%, 5 \%$, and $10 \%$-level. 
Table 3

Regression results for changes in loan loss provisions by past loan growth terciles

\begin{tabular}{|c|c|c|c|c|c|c|c|c|c|}
\hline \multirow{2}{*}{$\begin{array}{l}\text { Dep. Var.: LOGLL1 }{ }_{t} \\
\text { Explanatory Var. }\end{array}$} & \multicolumn{3}{|c|}{$\begin{array}{l}\text { Lower tercile: } \\
\text { Low growth in t-3 }\end{array}$} & \multicolumn{3}{|c|}{$\begin{array}{l}\text { Mid tercile: } \\
\text { Moderate growth in } \mathrm{t}-3\end{array}$} & \multicolumn{3}{|c|}{$\begin{array}{l}\text { Upper tercile: } \\
\text { High growth in t-3 }\end{array}$} \\
\hline & Coeff. & & p-val. & Coeff. & & p-val. & Coeff. & & p-val. \\
\hline LOGLL $_{\mathrm{t}-1}$ & 0.589860 & $* * *$ & 0.000 & 0.588965 & $* * *$ & 0.000 & 0.620102 & $* * *$ & 0.000 \\
\hline $\mathrm{LG}_{\mathrm{t}-1}$ & 0.000421 & & 0.589 & -0.001589 & $* *$ & 0.034 & -0.000909 & & 0.133 \\
\hline $\mathrm{LG}_{\mathrm{t}-2}$ & 0.001965 & $* * *$ & 0.006 & 0.000871 & & 0.225 & 0.000628 & & 0.277 \\
\hline $\mathrm{LG}_{\mathrm{t}-3}$ & 0.001208 & & 0.584 & 0.015848 & $* * *$ & 0.000 & 0.000726 & $*$ & 0.060 \\
\hline $\mathrm{LG}_{\mathrm{t}-4}$ & 0.000402 & & 0.478 & 0.001380 & $* *$ & 0.040 & 0.000487 & & 0.141 \\
\hline LOGTCL $_{t}$ & -0.005548 & & 0.491 & -0.002338 & & 0.745 & 0.013747 & $*$ & 0.077 \\
\hline GDP_GROW $_{t}$ & -0.083662 & $* * *$ & 0.000 & -0.055558 & $* * *$ & 0.003 & -0.036721 & $* *$ & 0.024 \\
\hline INT_L $\mathrm{LONG}_{\mathrm{t}}$ & 0.290450 & $* * *$ & 0.000 & 0.286410 & $* * *$ & 0.000 & 0.372145 & $* * *$ & 0.000 \\
\hline S_BHHC & 0.000302 & & 0.993 & -0.029075 & & 0.290 & 0.021075 & & 0.467 \\
\hline S_COOP & -0.159705 & $* * *$ & 0.000 & -0.277958 & $* * *$ & 0.000 & -0.179914 & $* * *$ & 0.000 \\
\hline S_MLTC & -0.300320 & $*$ & 0.091 & -0.201367 & & 0.564 & 0.196356 & & 0.556 \\
\hline S_REMB & -1.169470 & $* * *$ & 0.000 & -0.781940 & $* * *$ & 0.000 & -0.502115 & $* * *$ & 0.000 \\
\hline S_SAV & -0.099862 & $* *$ & 0.012 & -0.260532 & $* * *$ & 0.000 & -0.100896 & $* * *$ & 0.009 \\
\hline+- country dummies & & & & & & & & & \\
\hline Constant & -3.205843 & $* * *$ & 0.000 & -3.678003 & $* * *$ & 0.000 & -4.24623 & $* * *$ & 0.000 \\
\hline No of obs. & 5,719 & & & 6,343 & & & 6,221 & & \\
\hline No of clusters & 4,085 & & & 4,633 & & & 4,321 & & \\
\hline Adj. $\mathrm{R}^{2}$ & 0.506 & & & 0.524 & & & 0.506 & & \\
\hline
\end{tabular}

Notes: The dependent variable is the natural logarithm of the ratio of loan losses in t (LOGLL1), defined as the fraction of changes in total loan loss provisions in $t$ over the total amount of customer loans in $t-1$. Explanatory variables are the lags 1-4 of loan growth (LG), as well as the lagged dependent variable. We control for bankspecific effects using the logarithm of total customer loans (LOGTCL) and indicator dummy variables for each bank specialization: Commercial banks form the reference group, whereas Bank Holdings \& Holding Companies are denoted by S_BHHC=1, Cooperative Banks by S_COOP=1, Medium \& Long Term Credit Banks by S_MLTC=1, Real Estate / Mortgage Banks by S_REMB=1, and Savings Banks by S_SAV=1. As macroeconomic control variables, the GDP growth rate (GDP_GROW) and the 10-year government bond yield (INT_LONG) are included, as well as country dummies. This analysis differentiates whether the growth rate of a bank's total loans in t-3 (versus t-4) was below the 33.3\%-quantile (in the lower tercile) of loan growth for all banks in the respective country and year, above the 66.7\%-quantile (upper tercile), or in between (mid tercile). Pvalues are calculated from Huber-White robust standard errors, controlling for clustering at individual banks. $* * *, * *, *$ indicate that coefficients are statistically significant at the $1 \%, 5 \%$, and $10 \%$-level. 
Table 4

Regression results for the relative gross interest income

\begin{tabular}{|c|c|c|c|c|c|c|c|c|c|}
\hline Dep. Var.: $\Delta \mathrm{RII}_{\mathrm{t}}$ & \multicolumn{3}{|c|}{ (1) } & \multicolumn{3}{|c|}{$(2)$} & \multicolumn{3}{|c|}{ (3) } \\
\hline Explanatory Var. & Coeff. & & p-val. & Coeff. & & p-val. & Coeff. & & p-val. \\
\hline $\mathrm{LG}_{\mathrm{t}}$ & -0.005376 & $* * *$ & 0.000 & -0.005118 & $* * *$ & 0.000 & -0.006070 & $* * *$ & 0.000 \\
\hline LOGTCL $_{t}$ & 0.038956 & $* * *$ & 0.000 & 0.031015 & $* * *$ & 0.000 & 0.021100 & $* * *$ & 0.000 \\
\hline INFLAT $_{t}$ & 1.014770 & $* * *$ & 0.000 & 0.770179 & $* * *$ & 0.000 & & & \\
\hline GDP_GROW $_{\mathrm{t}}$ & & & & & & & 0.190246 & $* * *$ & 0.000 \\
\hline INT_LONG & 0.829046 & $* * *$ & 0.000 & & & & & & \\
\hline TERM $_{t}$ & & & & -0.383842 & $* * *$ & 0.000 & -0.453709 & $* * *$ & 0.000 \\
\hline S_BHHC & -0.048438 & $* * *$ & 0.000 & -0.027508 & $* *$ & 0.042 & -0.082030 & $* * *$ & 0.000 \\
\hline S_COOP & 0.189280 & $* * *$ & 0.000 & 0.203136 & $* * *$ & 0.000 & 0.182999 & $* * *$ & 0.000 \\
\hline $\mathrm{S}_{-}^{-} \mathrm{MLTC}$ & 0.677270 & $* * *$ & 0.000 & 0.676528 & $* * *$ & 0.000 & 0.723114 & $* * *$ & 0.000 \\
\hline S_REMB & 0.335139 & $* * *$ & 0.000 & 0.377282 & $* * *$ & 0.000 & 0.372411 & $* * *$ & 0.000 \\
\hline S_SAV & 0.078957 & $* * *$ & 0.001 & 0.096312 & $* * *$ & 0.000 & 0.049450 & $* *$ & 0.049 \\
\hline+ country dummies & & & & & & & & & \\
\hline Constant & -6.982515 & $* * *$ & 0.000 & -1.885689 & $* * *$ & 0.000 & -0.772027 & $* * *$ & 0.000 \\
\hline No of obs. & 49,907 & & & 49,907 & & & 49,907 & & \\
\hline No of clusters & 10,228 & & & 10,228 & & & 10,228 & & \\
\hline Adj. $R^{2}$ & 0.175 & & & 0.166 & & & 0.104 & & \\
\hline
\end{tabular}

Notes: The dependent variable is the absolute change from $\mathrm{t}-1$ to $\mathrm{t}$ of the relative gross interest income (RII, defined as the fraction of total interest income in $t$ over the average of total customer loans in $t-1$ and $t$ ). Explanatory variables are the contemporaneous loan growth (LG) and the logarithm of total customer loans (LOGTCL). We control for further bank-specific effects using indicator dummy variables for each bank specialization: Commercial banks form the reference group, whereas Bank Holdings \& Holding Companies are denoted by S_BHHC=1, Cooperative Banks by S_COOP=1, Medium and Long Term Credit Banks by S_MLTC $=1$, Real Estate \& Mortgage Banks by S_REMB=1, and Savings Banks by S_SAV=1. As macroeconomic control variables, the inflation rate (INFLAT), the GDP growth rate (GDP_GROW), the 10-year government bond yield (INT_LONG) and the term premium of interest rates (TERM $=10$-year government bond yield minus 3-month interest rate) for the respective country are included, as well as country dummies. Pvalues are calculated from Huber-White robust standard errors, controlling for clustering at individual banks. $* * *, * *, *$ indicate that coefficients are statistically significant at the $1 \%, 5 \%$, and $10 \%$-level. 
Table 5

Regression results for the gross interest income by bank specialization and country

Panel A: Differentiation by bank specialization

\begin{tabular}{|c|c|c|c|c|c|c|c|c|c|c|c|c|c|c|c|}
\hline \multirow{2}{*}{$\begin{array}{l}\text { Dep. Var.: } \Delta \mathrm{RII}_{\mathrm{t}} \\
\text { Explanatory Var. }\end{array}$} & \multicolumn{3}{|c|}{$\begin{array}{c}\text { (1) } \\
\text { Bank Hold. \& Holding Comp. }\end{array}$} & \multicolumn{3}{|c|}{$\begin{array}{c}(2) \\
\text { Commercial Banks }\end{array}$} & \multicolumn{3}{|c|}{$\begin{array}{c}\text { (3) } \\
\text { Cooperative Banks } \\
\end{array}$} & \multicolumn{3}{|c|}{$\begin{array}{c}(4) \\
\text { Savings Banks } \\
\end{array}$} & \multicolumn{3}{|c|}{$\begin{array}{c}(5) \\
\text { Other Bank Types }\end{array}$} \\
\hline & Coeff. & & p-val. & Coeff. & & p-val. & Coeff. & & p-val. & Coeff. & & p-val. & Coeff. & & p-val. \\
\hline $\mathrm{LG}_{\mathrm{t}}$ & -0.001358 & & 0.447 & -0.008368 & $* * *$ & 0.000 & 0.014643 & $* * *$ & 0.000 & -0.012309 & **** & 0.005 & -0.014545 & * & 0.061 \\
\hline LOGTCL $_{t}$ & 0.034240 & $* * *$ & 0.000 & 0.079652 & $* * *$ & 0.000 & 0.123210 & **** & 0.000 & -0.020954 & & 0.117 & 0.086045 & *** & 0.003 \\
\hline INFLAT $_{t}$ & 1.328151 & *** & 0.000 & 1.171158 & $* * *$ & 0.000 & 1.894241 & *** & 0.000 & 0.518516 & $* * *$ & 0.000 & 0.155605 & & 0.200 \\
\hline $\begin{array}{l}\mathrm{INT}_{-} \mathrm{LONG}_{\mathrm{t}} \\
+ \text { country dummies }\end{array}$ & 0.454099 & $* * *$ & 0.000 & 0.331556 & $* * *$ & 0.000 & 3.264461 & $* * *$ & 0.000 & 1.407583 & $* * *$ & 0.000 & 1.264561 & *** & 0.000 \\
\hline Constant & -6.337742 & $* * *$ & 0.000 & -5.492707 & $* * *$ & 0.000 & -19.916050 & $* * *$ & 0.000 & -8.062200 & $* * *$ & 0.000 & -6.792741 & $* * *$ & 0.000 \\
\hline No of obs. & 6,919 & & & 29,978 & & & 6,002 & & & 6,575 & & & 433 & & \\
\hline No of clusters & 1,376 & & & 6,333 & & & 1,164 & & & 1,272 & & & 83 & & \\
\hline Adj. $R^{2}$ & 0.275 & & & 0.166 & & & 0.534 & & & 0.199 & & & 0.161 & & \\
\hline
\end{tabular}

Panel B: Differentiation by country

\begin{tabular}{|c|c|c|c|c|c|c|c|c|c|c|c|c|c|c|}
\hline $\begin{array}{l}\text { Dep. Var.: } \Delta \mathrm{RII}_{\mathrm{t}} \\
\text { Explanatory var. }\end{array}$ & $\begin{array}{c}(1) \\
\text { Belgium }\end{array}$ & $\begin{array}{c}\text { (2) } \\
\text { Canada }\end{array}$ & $\begin{array}{c}(3) \\
\text { Denmark }\end{array}$ & $\begin{array}{c}\text { (4) } \\
\text { Erance }\end{array}$ & $\begin{array}{c}\text { (5) } \\
\text { Germany }\end{array}$ & (6) & $\begin{array}{c}\text { (7) } \\
\text { Luxemb }\end{array}$ & $\begin{array}{c}\text { (8) } \\
\text { Nethrands }\end{array}$ & $\begin{array}{c}\text { (9) } \\
\text { Norway }\end{array}$ & $\begin{array}{l}(10) \\
\text { Spain }\end{array}$ & $\begin{array}{l}(11) \\
\text { Sureden }\end{array}$ & $\begin{array}{c}\text { (12) } \\
\text { Switzerland }\end{array}$ & (13) & $\begin{array}{l}\text { (14) } \\
\text { USA }\end{array}$ \\
\hline$\overline{L G_{t}}$ & $\begin{array}{l}0.038203 \\
(0.083)^{*}\end{array}$ & $\begin{array}{l}-0.023480 \\
(0.003)^{* * *}\end{array}$ & $\begin{array}{l}-0.048852 \\
(0.022)^{* *}\end{array}$ & $\begin{array}{c}0.002623 \\
(0.837)\end{array}$ & $\begin{array}{c}0.012851 \\
(0.000)^{* * *}\end{array}$ & $\begin{array}{l}-0.018778 \\
(0.000)^{* * *}\end{array}$ & $\begin{array}{l}-0.051596 \\
(0.030)^{* *}\end{array}$ & $\begin{array}{c}0.002161 \\
(0.892)\end{array}$ & $\begin{array}{l}0.037364 \\
(0.019)^{* *}\end{array}$ & $\begin{array}{c}-0.026985 \\
(0.089)^{*}\end{array}$ & $\begin{array}{l}-0.060415 \\
(0.043)^{* *}\end{array}$ & $\begin{array}{l}-0.029696 \\
(0.006) * * *\end{array}$ & $\begin{array}{c}0.004154 \\
(0.681)\end{array}$ & $\begin{array}{l}-0.006813 \\
(0.000)^{* * *}\end{array}$ \\
\hline LOGTCL $_{t}$ & $\begin{array}{c}0.020251 \\
(0.890)\end{array}$ & $\begin{array}{c}-0.016337 \\
(0.644)\end{array}$ & $\begin{array}{l}0.216318 \\
(0.067)^{*}\end{array}$ & $\begin{array}{c}-0.064667 \\
(0.287)\end{array}$ & $\begin{array}{c}0.091237 \\
(0.000) * * *\end{array}$ & $\begin{array}{c}0.181476 \\
(0.000) * * *\end{array}$ & $\begin{array}{c}-0.070995 \\
(0.804)\end{array}$ & $\begin{array}{c}0.255474 \\
(0.171)\end{array}$ & $\begin{array}{c}-0.059198 \\
(0.407)\end{array}$ & $\begin{array}{l}0.341535 \\
(0.027)^{* *}\end{array}$ & $\begin{array}{c}0.136036 \\
(0.209)\end{array}$ & $\begin{array}{l}0.368053 \\
(0.023)^{* *}\end{array}$ & $\begin{array}{c}0.068071 \\
(0.290)\end{array}$ & $\begin{array}{r}0.075626 \\
(0.000)^{* * *}\end{array}$ \\
\hline INFLAT $_{t}$ & $\begin{array}{c}3.014990 \\
(0.000)^{* * *}\end{array}$ & $\begin{array}{c}0.190923 \\
(0.158)\end{array}$ & $\begin{array}{c}1.929353 \\
(0.000)^{* * *}\end{array}$ & $\begin{array}{c}1.654094 \\
(0.000)^{* * *}\end{array}$ & $\begin{array}{c}1.331789 \\
(0.000)^{* * *}\end{array}$ & $\begin{array}{c}3.082695 \\
(0.000) * * *\end{array}$ & $\begin{array}{l}-0.616011 \\
(0.030)^{* *}\end{array}$ & $\begin{array}{c}0.661891 \\
(0.000)^{* * *}\end{array}$ & $\begin{array}{l}-0.096809 \\
(0.000)^{* * *}\end{array}$ & $\begin{array}{c}2.399024 \\
(0.000) * * *\end{array}$ & $\begin{array}{c}0.495150 \\
(0.001)^{* * *}\end{array}$ & $\begin{array}{c}-0.479278 \\
(0.368)\end{array}$ & $\begin{array}{c}-0.134867 \\
(0.626)\end{array}$ & $\begin{array}{c}1.433725 \\
(0.000)^{* * *}\end{array}$ \\
\hline $\begin{array}{l}\text { INT_LONG } \\
+ \text { special. dummies }\end{array}$ & $\begin{array}{c}2.283942 \\
(0.000)^{* * * *}\end{array}$ & $\begin{array}{c}0.105766 \\
(0.632)\end{array}$ & $\begin{array}{c}1.383884 \\
(0.000)^{* * *}\end{array}$ & $\begin{array}{c}2.443625 \\
(0.000)^{* * *}\end{array}$ & $\begin{array}{l}3.037176 \\
(0.000)^{* * * *}\end{array}$ & $\begin{array}{c}3.745677 \\
(0.000)^{* * *}\end{array}$ & $\begin{array}{c}0.949067 \\
(0.107)\end{array}$ & $\begin{array}{c}0.588167 \\
(0.275)\end{array}$ & $\begin{array}{l}2.117780 \\
(0.000)^{* * *}\end{array}$ & $\begin{array}{c}2.439923 \\
(0.000)^{* * *}\end{array}$ & $\begin{array}{c}1.915281 \\
(0.000)^{* * *}\end{array}$ & $\begin{array}{l}3.642797 \\
(0.000)^{* * *}\end{array}$ & $\begin{array}{l}-0.641767 \\
(0.073)^{* *}\end{array}$ & $\begin{array}{c}0.242805 \\
(0.000)^{* * *}\end{array}$ \\
\hline No of obs. & 149 & 170 & 400 & 1011 & 7,139 & 2,374 & 99 & 83 & 131 & 458 & 101 & 194 & 368 & 37,230 \\
\hline No of clusters & 29 & 30 & 73 & 203 & 1,332 & 467 & 21 & 17 & 26 & 87 & 22 & 41 & 71 & 7,809 \\
\hline Adj. $R^{2}$ & 0.178 & 0.030 & 0.432 & 0.392 & 0.392 & 0.672 & 0.171 & 0.175 & 0.576 & 0.480 & 0.479 & 0.235 & 0.000 & 0.277 \\
\hline
\end{tabular}

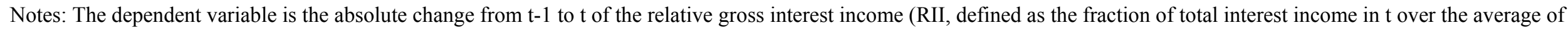

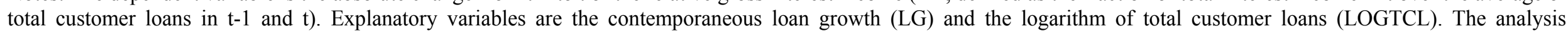
differentiates between bank specializations by using separate regression models (1) to (5) in panel A whereas models (1) to (14) in panel B differentiate between countries. The model (5) in panel A (“Other Bank Types") analyzes Medium \& Long Term Credit Banks and Real Estate / Mortgage banks. In panel B, we control for bank-specific effects

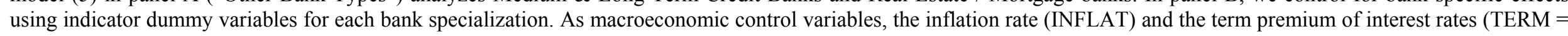
10-year government bond yield minus 3-month interest rate) are included, as well as country dummies in panel A. P-values are calculated from Huber-White robust standard errors, controlling for clustering at individual banks. $* * *, * * *$ indicate that coefficients are statistically significant at the $1 \%, 5 \%$, and $10 \%$-level. 
Table 6

Regression results for the equity-to-total assets ratio

\begin{tabular}{|c|c|c|c|c|c|c|c|c|c|}
\hline Dep. Var.: $\Delta \mathrm{ETA}_{t}$ & \multicolumn{3}{|c|}{ (1) } & \multicolumn{3}{|c|}{$(2)$} & \multicolumn{3}{|c|}{ (3) } \\
\hline Explanatory Var. & Coeff. & & p-val. & Coeff. & & p-val. & Coeff. & & p-val. \\
\hline $\mathrm{LG}_{\mathrm{t}}$ & -0.025112 & $* * *$ & 0.000 & -0.025048 & $* * *$ & 0.000 & -0.025171 & $* * *$ & 0.000 \\
\hline LOGTCL $_{t}$ & 0.087137 & $* * *$ & 0.000 & 0.086021 & $* * *$ & 0.000 & 0.086614 & $* * *$ & 0.000 \\
\hline INFLAT $_{t}$ & -0.070403 & $* * *$ & 0.000 & -0.082730 & $* * *$ & 0.000 & & & \\
\hline GDP_GROW $_{\mathrm{t}}$ & & & & & & & 0.024942 & $* * *$ & 0.000 \\
\hline INT_L $\mathrm{LNG}_{\mathrm{t}}$ & 0.048860 & $* * *$ & 0.000 & & & & 0.056830 & $* * *$ & 0.000 \\
\hline TERM $_{t}$ & & & & -0.017614 & $* * *$ & 0.001 & & & \\
\hline S_BHHC & -0.112861 & $* * *$ & 0.000 & -0.111689 & $* * *$ & 0.000 & -0.110650 & $* * *$ & 0.000 \\
\hline S_COOP & 0.153834 & $* * *$ & 0.000 & 0.153720 & $* * *$ & 0.000 & 0.153894 & $* * *$ & 0.000 \\
\hline S_MLTC & -0.085816 & & 0.412 & -0.084826 & & 0.417 & -0.084706 & & 0.417 \\
\hline S_REMB & -0.254918 & $* * *$ & 0.000 & -0.252234 & $* * *$ & 0.000 & -0.253816 & $* * *$ & 0.000 \\
\hline S_SAV & -0.009521 & & 0.660 & -0.008719 & & 0.687 & -0.007725 & & 0.721 \\
\hline+ country dummies & & & & & & & & & \\
\hline Constant & -0.374458 & $* * *$ & 0.001 & -0.084101 & & 0.412 & -0.578991 & $* * *$ & 0.000 \\
\hline No of obs. & 60,050 & & & 60,050 & & & 60,050 & & \\
\hline No of clusters & 10,228 & & & 10,228 & & & 10,228 & & \\
\hline Adj. $R^{2}$ & 0.129 & & & 0.128 & & & 0.128 & & \\
\hline
\end{tabular}

Notes: The dependent variable is the absolute change of the equity-to-total assets ratio from t- 1 to $\mathrm{t}(\Delta \mathrm{ETA})$. Explanatory variables are the contemporaneous loan growth (LG) and the natural logarithm of total customer loans (LOGTCL). We control for further bank-specific effects using indicator dummy variables for each bank specialization: Commercial banks form the reference group, whereas Bank Holdings \& Holding Companies are denoted by $\mathrm{S} \_\mathrm{BHHC}=1$, Cooperative Banks by S_COOP=1, Medium \& Long Term Credit Banks by S_MLTC $=1$, Real Estate / Mortgage Banks by $\bar{S}$ REMB=1, and Savings Banks by S_SAV=1. As macroeconomic control variables, the GDP growth rate (GDP_GROW), the inflation rate (INFLAT), the 10-year government bond yield (INT_LONG), and the term premium of interest rates (TERM $=10$-year government bond yield minus 3-month interest rate) for the respective country are included, as well as country dummies. Pvalues are calculated from Huber-White robust standard errors, controlling for clustering at individual banks. $* * *, * *, *$ indicate that coefficients are statistically significant at the $1 \%, 5 \%$, and $10 \%$-level. 


\section{Table 7}

Interaction effects from mergers and acquisitions in the banking industry

Panel A: Loan growth and loan losses (H1)

\begin{tabular}{|c|c|c|c|}
\hline Dep. Var.: LOGLL1 ${ }_{t}$ & & & \\
\hline Explanatory Var. & Coeff. & & p-val. \\
\hline LOGLL1 $_{t-1}$ & 0.602720 & $* * *$ & 0.000 \\
\hline $\mathrm{LG}_{\mathrm{t}-1}$ & 0.000701 & & 0.231 \\
\hline $\mathrm{LG}_{\mathrm{t}-1} \mathrm{X}$ MERGE $\mathrm{E}_{\mathrm{t}-1}$ & -0.002704 & $* * *$ & 0.000 \\
\hline $\mathrm{LG}_{\mathrm{t}-2}$ & 0.001347 & $* *$ & 0.019 \\
\hline $\mathrm{LG}_{\mathrm{t}-2} \mathrm{X}$ MERGE $\mathrm{E}_{\mathrm{t}-2}$ & -0.000345 & & 0.577 \\
\hline $\mathrm{LG}_{\mathrm{t}-3}$ & 0.002920 & $* * *$ & 0.000 \\
\hline $\mathrm{LG}_{\mathrm{t}-3} \times \mathrm{MERGE}_{\mathrm{t}-3}$ & -0.001730 & $* * *$ & 0.001 \\
\hline $\mathrm{LG}_{\mathrm{t}-4}$ & 0.000927 & $* * *$ & 0.006 \\
\hline $\mathrm{LG}_{\mathrm{t}-4} \mathrm{X}$ MERGE $\mathrm{Mt}_{\mathrm{t}-4}$ & -0.001008 & $* *$ & 0.021 \\
\hline LOGTCL $_{t}$ & 0.004135 & & 0.379 \\
\hline GDP_GROW $_{t}$ & -0.061343 & $* * *$ & 0.000 \\
\hline INT_L_ONG & 0.324132 & $* * *$ & 0.000 \\
\hline Constant & -3.791370 & $* * *$ & 0.000 \\
\hline No. of obs. & 18,204 & & \\
\hline No. of clusters & 8,658 & & \\
\hline Adj. $R^{2}$ & 0.516 & & \\
\hline
\end{tabular}

Panel B: Loan growth and interest income (H2)

\begin{tabular}{|c|c|c|c|}
\hline Dep. Var.: $\Delta \mathrm{RII}_{\mathrm{t}}$ & & & \\
\hline Explanatory Var. & Coeff. & & p-val. \\
\hline $\mathrm{LG}_{\mathrm{t}}$ & -0.020220 & $* * *$ & 0.000 \\
\hline $\mathrm{LG}_{\mathrm{t}} \mathrm{X} \mathrm{MERGE}_{\mathrm{t}}$ & 0.028860 & $* * *$ & 0.000 \\
\hline LOGTCL $_{t}$ & 0.035244 & $* * *$ & 0.000 \\
\hline INFLAT $_{t}$ & 1.021699 & $* * *$ & 0.000 \\
\hline INT_LONG & 0.837091 & $* * *$ & 0.000 \\
\hline Constant & -6.887036 & $* * *$ & 0.000 \\
\hline No. of obs. & 49,906 & & \\
\hline No. of clusters & 10,228 & & \\
\hline Adj. $\mathrm{R}^{2}$ & 0.205 & & \\
\hline
\end{tabular}

Panel C: Loan growth and bank solvency (H3)

\begin{tabular}{|c|c|c|c|}
\hline Dep. Var.: $\Delta$ ETA $_{t}$ & & & \\
\hline Explanatory Var. & Coeff. & & p-val. \\
\hline $\mathrm{LG}_{\mathrm{t}}$ & -0.048254 & $* * *$ & 0.000 \\
\hline $\mathrm{LG}_{\mathrm{t}} \mathrm{X} \mathrm{MERGE}_{\mathrm{t}}$ & 0.051621 & $* * *$ & 0.000 \\
\hline LOGTCL $_{t}$ & 0.064975 & $* * *$ & 0.000 \\
\hline INFLAT $_{\mathrm{t}}$ & -0.052241 & $* * *$ & 0.000 \\
\hline INT_LONG & 0.095386 & $* * *$ & 0.000 \\
\hline Constant & -0.288125 & $* * *$ & 0.005 \\
\hline No. of obs. & 60,049 & & \\
\hline No. of clusters & 10,228 & & \\
\hline Adj. $R^{2}$ & 0.287 & & \\
\hline
\end{tabular}

Notes: These tables report results for hypotheses H1-H3 taking into account the M\&A activity of banks. M\&A effects are considered by an interacted indicator variable MERGE ( $=1$ if a bank's total equity increases by more than $40.0 \%$, which corresponds to the $95 \%$ percentile of the equity growth rate distribution). All regressions also include bank specialization and country dummies (not reported here). P-values are calculated from Huber-White robust standard errors, controlling for clustering at individual banks. ***,**, * indicate that coefficients are statistically significant at the $1 \% ; 5 \%$, and $10 \%$-level. 
Table 8

Differentiation of regression results by banks' capitalization

Panel A: Regression results for changes in loan loss provisions

\begin{tabular}{|c|c|c|c|c|c|c|c|c|c|}
\hline \multirow{2}{*}{$\begin{array}{l}\text { Dep. Var.: LOGLL1 }{ }_{\mathrm{t}} \\
\text { Explanatory Var. }\end{array}$} & \multicolumn{3}{|c|}{$\begin{array}{l}\text { Lower tercile: } \\
\text { Low ETA in } \mathrm{t}-3\end{array}$} & \multicolumn{3}{|c|}{$\begin{array}{c}\text { Mid tercile: } \\
\text { Moderate ETA in t-3 }\end{array}$} & \multicolumn{3}{|c|}{$\begin{array}{c}\text { Upper tercile: } \\
\text { High ETA in t-3 }\end{array}$} \\
\hline & Coeff. & & p-val. & Coeff. & & p-val. & Coeff. & & p-val. \\
\hline LOGLL1 $_{\mathrm{t}-1}$ & 0.578027 & $* * *$ & 0.000 & 0.554029 & $* * *$ & 0.000 & 0.655990 & $* * *$ & 0.000 \\
\hline $\mathrm{LG}_{\mathrm{t}-1}$ & -0.000812 & & 0.242 & -0.000791 & & 0.255 & -0.000361 & & 0.623 \\
\hline $\mathrm{LG}_{\mathrm{t}-2}$ & 0.001559 & $* * *$ & 0.009 & 0.001421 & $* *$ & 0.033 & 0.000895 & & 0.196 \\
\hline $\mathrm{LG}_{\mathrm{t}-3}$ & 0.002544 & $* * *$ & 0.000 & 0.001914 & $* * *$ & 0.000 & 0.001135 & $* *$ & 0.038 \\
\hline $\mathrm{LG}_{\mathrm{t}-4}$ & 0.000822 & & 0.102 & 0.001041 & $* *$ & 0.012 & 0.000023 & & 0.957 \\
\hline LOGTCL $_{t}$ & -0.003662 & & 0.617 & 0.009903 & & 0.225 & 0.013942 & & 0.135 \\
\hline GDP_GROW $_{t}$ & -0.071826 & $* * *$ & 0.000 & -0.078556 & $* * *$ & 0.000 & -0.028976 & & 0.157 \\
\hline $\begin{array}{l}\text { INT_L } \mathrm{LONG}_{\mathrm{t}} \\
+ \text { special./country dummies }\end{array}$ & 0.300154 & $* * *$ & 0.000 & 0.362790 & $* * *$ & 0.000 & 0.303525 & $* * *$ & 0.000 \\
\hline Constant & -4.001158 & $* * *$ & 0.000 & -4.055786 & $* * *$ & 0.000 & -3.511551 & $* * *$ & 0.000 \\
\hline No of obs. & 6,293 & & & 6,366 & & & 5,624 & & \\
\hline No of clusters & 3,510 & & & 3,846 & & & 3,154 & & \\
\hline Adj. $R^{2}$ & 0.512 & & & 0.494 & & & 0.541 & & \\
\hline
\end{tabular}

Panel B: Regression results for the relative gross interest income

\begin{tabular}{|c|c|c|c|c|c|c|c|c|c|}
\hline Dep. Var.: $\Delta \mathrm{RII}$ & $\begin{array}{l}\text { Lowe } \\
\text { Low }\end{array}$ & $\begin{array}{l}\text { terc } \\
\text { eTA }\end{array}$ & & $\begin{array}{r}\text { Mid } \\
\text { Modera }\end{array}$ & $\begin{array}{l}\text { tercil } \\
\text { e ET }\end{array}$ & in $\mathrm{t}$ & $\begin{array}{l}\text { Uppe } \\
\text { High }\end{array}$ & $\begin{array}{l}\text { terc } \\
\text { ETA }\end{array}$ & \\
\hline Explanatory Var. & Coeff. & & p-val. & Coeff. & & p-val. & Coeff. & & p-val. \\
\hline $\mathrm{LG}_{\mathrm{t}}$ & -0.008333 & $* * *$ & 0.000 & -0.001964 & $*$ & 0.093 & -0.006434 & $* * *$ & 0.000 \\
\hline LOGTCL $_{t}$ & 0.004284 & & 0.631 & 0.020209 & $* * *$ & 0.008 & 0.082727 & $* * *$ & 0.000 \\
\hline INFLAT $_{t}$ & 1.006689 & $* * *$ & 0.000 & 1.019895 & $* * *$ & 0.000 & 1.014140 & $* * *$ & 0.000 \\
\hline $\begin{array}{l}\text { INT_LONG } \\
+ \text { special./country dummies }\end{array}$ & 0.875277 & $* * *$ & 0.000 & 0.789472 & $* * *$ & 0.000 & 0.833566 & $* * *$ & 0.000 \\
\hline Constant & -7.173966 & $* * *$ & 0.000 & -6.684929 & $* * *$ & 0.000 & -7.085848 & $* * *$ & 0.000 \\
\hline No of obs. & 16,877 & & & 16,858 & & & 16,172 & & \\
\hline No of clusters & 5,142 & & & 6,089 & & & 4,812 & & \\
\hline Adj. $R^{2}$ & 0.177 & & & 0.202 & & & 0.160 & & \\
\hline
\end{tabular}

\begin{tabular}{|c|c|c|c|c|c|c|c|c|c|}
\hline \multicolumn{10}{|c|}{ Panel C: Regression results for the equity-to-total-assets ratio } \\
\hline Dep. Var.: $\triangle$ ETA & \multicolumn{3}{|c|}{$\begin{array}{l}\text { Lower tercile: } \\
\text { Low ETA in } \mathrm{t}\end{array}$} & \multicolumn{3}{|c|}{$\begin{array}{c}\text { Mid tercile: } \\
\text { Moderate ETA in } \mathrm{t}\end{array}$} & \multicolumn{3}{|c|}{$\begin{array}{l}\text { Upper tercile: } \\
\text { High ETA in } \mathrm{t}\end{array}$} \\
\hline Explanatory Var. & Coeff. & & p-val. & Coeff. & & p-val. & Coeff. & & p-val. \\
\hline $\mathrm{LG}_{\mathrm{t}}$ & -0.014539 & $* * *$ & 0.000 & -0.019789 & $* * *$ & 0.000 & -0.033562 & $* * *$ & 0.000 \\
\hline LOGTCL $_{t}$ & -0.069457 & $* * *$ & 0.000 & -0.075712 & $* * *$ & 0.000 & -0.081792 & $* * *$ & 0.000 \\
\hline $\operatorname{INFLAT}_{\mathrm{t}}$ & -0.053631 & $* * *$ & 0.000 & 0.007611 & & 0.287 & 0.136127 & $* * *$ & 0.000 \\
\hline $\begin{array}{l}\text { INT_LONG } \\
+ \text { special./country dummies }\end{array}$ & 0.157609 & $* * *$ & 0.000 & 0.050336 & $* * *$ & 0.000 & -0.118645 & $* * *$ & 0.000 \\
\hline Constant & -0.343539 & $* * *$ & 0.001 & 0.017526 & & 0.870 & 1.110838 & $* * *$ & 0.000 \\
\hline No of obs. & 20,137 & & & 20,234 & & & 19,679 & & \\
\hline No of clusters & 5,361 & & & 6,463 & & & 5,174 & & \\
\hline Adj. $\mathrm{R}^{2}$ & 0.098 & & & 0.122 & & & 0.155 & & \\
\hline
\end{tabular}

Notes: These analyses differentiate whether a bank's equity-to-total-assets ratio (ETA) was below the $33.3 \%$ quantile (in the lower tercile) of ETA for all banks in the respective country and year, above the $66.7 \%$-quantile (upper tercile), or in between (mid tercile). Panel A tests $\mathrm{H} 1$ and explains the natural logarithm of the ratio of loan losses in t (LOGLL1), as defined above, by the lags 1-4 of loan growth (LG), as well as the lagged dependent variable. In Panel B (testing H2) and Panel C (testing H3), respectively, the absolute change from t-1 to $t$ of the relative interest income $(\Delta \mathrm{RII})$, or the absolute change of the equity-to-total-assets ratio $(\Delta \mathrm{ETA})$ are explained by the contemporaneous loan growth rate (LG). In all panels, we control for bank-specific effects using the logarithm of total customer loans (LOGTCL) and indicator dummy variables for each bank specialization. As macroeconomic control variables serve the GDP growth rate (GDP_GROW) or the inflation rate (INFLAT), as well as the 10-year government bond yield (INT_LONG) and country dummies. P-values are calculated from Huber-White robust standard errors, controlling for clustering at individual banks. ***,**,* indicate that coefficients are statistically significant at the $1 \%, 5 \%$, and $10 \%$-level. 


\section{Table 9}

Regression results for risk-adjusted relative interest income

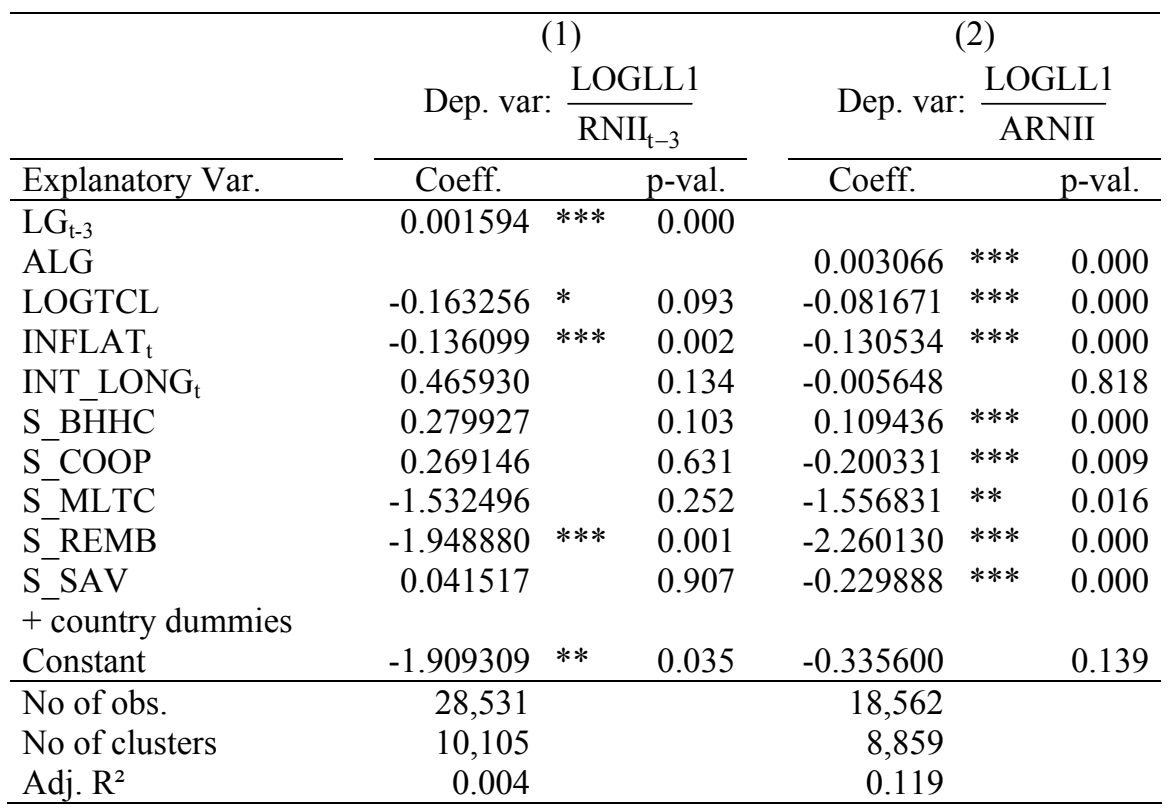

Notes: The dependent variable is the ratio of the natural logarithm of loan losses (LOGLL1) in $t$ to the relative net interest income (RNII) in the preceding years. The denominator is measured alternatively as $\mathrm{RNII}_{\mathrm{t}-3}$ in model (1), or as the average relative net interest income $A R N I I=\left(\mathrm{RNII}_{t-1}+\mathrm{RNII}_{\mathrm{t}-2}+\mathrm{RNII}_{\mathrm{t}-3}+\mathrm{RNII}_{\mathrm{t}-4}\right) / 4$ in model (2). Explanatory variables are loan growth (LG) in the time period that corresponds to the measure of RNII used, and the natural logarithm of total customer loans (LOGTCL). We control for further bank-specific effects using indicator dummy variables for each bank specialization: Commercial banks form the reference group, whereas Bank Holdings \& Holding Companies are denoted by S_BHHC=1, Cooperative Banks by S_COOP=1, Medium \& Long Term Credit Banks by S_MLTC=1, Real Estate / Mortgage Banks by S_REMB=1, and Savings Banks by $\mathrm{S} S A V=1$. As macroeconomic control variables, the inflation rate (INFLAT) and the 10 -year government bond yield (INT LONG) are included, as well as country dummies. P-values are calculated from Huber-White robust standard errors, controlling for clustering at individual banks. $* * *, * *, *$ indicate that coefficients are statistically significant at the $1 \%, 5 \%$, and $10 \%$-level. 
Table 10

Modified VAR model for loan losses and loan growth

\begin{tabular}{|c|c|c|c|c|c|c|}
\hline \multirow{2}{*}{$\frac{\text { Dep. Var.: }}{\text { Explanatory Var. }}$} & \multicolumn{3}{|c|}{$\begin{array}{c}(1) \\
\text { LOGLL1 }\end{array}$} & \multicolumn{3}{|c|}{$\begin{array}{l}(2) \\
L_{t}\end{array}$} \\
\hline & Coeff. & & p-val. & Coeff. & & p-val. \\
\hline CUM LG LG $_{t-1}$ & 0.000164 & $* *$ & 0.028 & 0.036982 & $* * *$ & 0.000 \\
\hline CUM ${ }^{-} \mathrm{LL}_{\mathrm{t}-1}$ & 0.638411 & $* * *$ & 0.000 & -0.984136 & $* * *$ & 0.000 \\
\hline LOGTCL $_{t}$ & 0.015869 & $* * *$ & 0.003 & 1.241689 & $* * *$ & 0.000 \\
\hline S_BHHC & 0.019882 & & 0.362 & -1.712760 & $* * *$ & 0.000 \\
\hline $\mathrm{S}^{-} \mathrm{COOP}$ & -0.165532 & $* * *$ & 0.000 & 1.043624 & & 0.077 \\
\hline $\mathrm{S}^{-} \mathrm{MLTC}$ & -0.251571 & $*$ & 0.094 & -6.677946 & $* * *$ & 0.000 \\
\hline $\mathrm{S}^{-} \mathrm{REMB}$ & -0.724298 & $* * *$ & 0.000 & -5.347768 & $* * *$ & 0.000 \\
\hline S_SAV & -0.085305 & $* * *$ & 0.003 & -1.901822 & $* * *$ & 0.000 \\
\hline+ country dummie & & & & & & \\
\hline Constant & -6.171575 & $* * *$ & 0.000 & -3.035463 & & 0.217 \\
\hline No. of obs. & 18,486 & & & 19,075 & & \\
\hline No. of clusters & 8,815 & & & 8,946 & & \\
\hline Adj. $R^{2}$ & 0.451 & & & 0.126 & & \\
\hline
\end{tabular}

Notes: The dependent variable is the natural logarithm of the ratio of loan losses in t (LOGLL1), defined as the fraction of changes in total loan loss provisions in $t$ over the total amount of customer loans in t-1. Explanatory variables are the cumulative loan growth (CUM LG) in t-1 and the natural logarithm of cumulative loan losses (CUM LL1) in $\mathrm{t}-1$. Cumulative variables equal to the sum of the variable values from $\mathrm{t}-1, \mathrm{t}-2, \ldots$, and $\mathrm{t}-4$. We control for bank-specific effects using the logarithm of total customer loans (LOGTCL) and indicator dummy variables for each bank specialization: Commercial banks form the reference group, whereas Bank Holdings \& Holding Companies are denoted by $\mathrm{S} B H H C=1$, Cooperative Banks by $\mathrm{S} C O O P=1$, Medium \& Long Term Credit Banks by S_MLTC=1, Real Estate / Mortgage Banks by S_REMB=1 and Savings Banks by S_SAV=1. We also include country dummies. P-values are calculated from Huber-White robust standard errors, controlling for clustering at individual banks. ${ }^{* *}, * *, *$ indicate that coefficients are statistically significant at the $1 \%, 5 \%$, and $10 \%$-level. 
Table 11

Regression results using alternative measures of loan growth

Panel A: Regression results for changes in loan loss provisions

\begin{tabular}{|c|c|c|c|}
\hline Dep. Var.: LOGLL1 $1_{\mathrm{t}}$ & \multicolumn{3}{|c|}{ (1) } \\
\hline Explanatory Var. & Coeff. & & p-val. \\
\hline LOGLL1 $_{\mathrm{t}-1}$ & 0.602364 & $* * *$ & 0.000 \\
\hline $\mathrm{ALG}_{\mathrm{t}-1}$ & -0.000519 & & 0.211 \\
\hline $\mathrm{ALG}_{\mathrm{t}-2}$ & 0.001332 & $* * *$ & 0.000 \\
\hline $\mathrm{ALG}_{\mathrm{t}-3}$ & 0.001803 & $* * *$ & 0.000 \\
\hline $\mathrm{ALG}_{\mathrm{t}-4}$ & 0.000547 & $* *$ & 0.031 \\
\hline LOGTCL $_{t}$ & 0.003455 & & 0.457 \\
\hline $\mathrm{GDP}_{-} \mathrm{GROW}_{\mathrm{t}}$ & -0.064746 & $* * *$ & 0.000 \\
\hline $\begin{array}{l}\text { INT_LONG } \\
+ \text { special./country dummies }\end{array}$ & 0.334314 & $* * *$ & 0.000 \\
\hline Constant & -3.773602 & $* * *$ & 0.000 \\
\hline No of obs. & 18,283 & & \\
\hline No of clusters & 8,718 & & \\
\hline Adj. $\mathrm{R}^{2}$ & 0.515 & & \\
\hline
\end{tabular}

\begin{tabular}{|c|c|c|c|}
\hline Dep. Var.: LOGLL1 $1_{t}$ & \multicolumn{3}{|c|}{ (2) } \\
\hline Explanatory Var. & Coeff. & & p-val. \\
\hline LOGLL1 $_{\mathrm{t}-1}$ & 0.603397 & $* * *$ & 0.000 \\
\hline $\mathrm{DLG}_{\mathrm{t}-1}$ & 0.029170 & $* * *$ & 0.000 \\
\hline $\mathrm{DLG}_{\mathrm{t}-2}$ & 0.019247 & $* *$ & 0.018 \\
\hline $\mathrm{DLG}_{\mathrm{t}-3}$ & 0.042362 & $* * *$ & 0.000 \\
\hline $\mathrm{DLG}_{\mathrm{t}-4}$ & 0.009987 & & 0.194 \\
\hline LOGTCL $_{t}$ & 0.001250 & & 0.785 \\
\hline GDP_GROW $_{t}$ & -0.069157 & $* * *$ & 0.000 \\
\hline $\begin{array}{l}\text { INT_L̄ONG } \\
+ \text { special./country dummies }\end{array}$ & 0.332463 & $* * *$ & 0.000 \\
\hline Constant & -3.735917 & $* * *$ & 0.000 \\
\hline No of obs. & 18,283 & & \\
\hline No of clusters & 8,718 & & \\
\hline Adj. $R^{2}$ & 0.515 & & \\
\hline
\end{tabular}

Panel B: Regression results for the relative gross interest income

\begin{tabular}{|c|c|c|c|c|c|c|}
\hline Dep. Var.: $\Delta$ RII & \multicolumn{3}{|c|}{$(1)$} & \multicolumn{3}{|c|}{ (2) } \\
\hline Explanatory Var. & Coeff. & & p-val. & Coeff. & & p-val. \\
\hline $\mathrm{ALG}_{\mathrm{t}}$ & -0.004771 & $* * *$ & 0.000 & & & \\
\hline $\mathrm{DLG}_{\mathrm{t}}$ & & & & -0.187881 & $* * *$ & 0.000 \\
\hline LOGTCL $_{t}$ & 0.037314 & $* * *$ & 0.000 & 0.043973 & $* * *$ & 0.000 \\
\hline INFLAT $_{t}$ & 1.012819 & $* * *$ & 0.000 & 1.012953 & $* * *$ & 0.000 \\
\hline $\begin{array}{l}\mathrm{INT}_{2} \mathrm{LONG}_{\mathrm{t}} \\
+ \text { special./country dummies }\end{array}$ & 0.821683 & $* * *$ & 0.000 & 0.811990 & $* * *$ & 0.000 \\
\hline Constant & -6.968280 & $* * *$ & 0.000 & -6.970459 & $* * *$ & 0.000 \\
\hline No of obs. & 49,907 & & & 49,907 & & \\
\hline No of clusters & 10,228 & & & 10,228 & & \\
\hline Adj. $R^{2}$ & 0.174 & & & 0.180 & & \\
\hline
\end{tabular}

Panel C: Regression results for the equity-to-total-assets ratio

\begin{tabular}{|c|c|c|c|c|c|c|}
\hline Dep. Var.: $\Delta$ ETA & \multicolumn{3}{|c|}{$(1)$} & \multicolumn{3}{|c|}{ (2) } \\
\hline Explanatory Var. & Coeff. & & p-val. & Coeff. & & p-val. \\
\hline $\mathrm{ALG}_{\mathrm{t}}$ & -0.025152 & *** & 0.000 & & & \\
\hline $\mathrm{DLG}_{\mathrm{t}}$ & & & & -0.328402 & $* * *$ & 0.000 \\
\hline LOGTCL $_{t}$ & 0.084148 & $* * *$ & 0.000 & 0.074591 & $* * *$ & 0.000 \\
\hline INFLAT $_{t}$ & -0.076355 & $* * *$ & 0.000 & -0.069414 & $* * *$ & 0.000 \\
\hline $\begin{array}{l}\text { INT_LONG } \\
+ \text { special/country dummies }\end{array}$ & 0.000484 & & 0.960 & -0.046027 & $* * *$ & 0.000 \\
\hline Constant & -0.278580 & ** & 0.012 & -0.053447 & & 0.635 \\
\hline No of obs. & 60,050 & & & 60,050 & & \\
\hline No of clusters & 10,228 & & & 10,228 & & \\
\hline Adj. $\mathrm{R}^{2}$ & 0.128 & & & 0.042 & & \\
\hline
\end{tabular}

Notes: These analyses test the robustness of the analyses for hypotheses $\mathrm{H} 1-\mathrm{H} 3$ regarding two alternative measures of loan growth: First, ALG is defined as the difference between a bank's loan growth in year $t\left(\mathrm{LG}_{t}\right)$ and the median of loan growth across all banks in the respective country and year. The alternative measure, DLG, takes the value of -1 if $\mathrm{LG}_{\mathrm{t}}$ was below the $33.3 \%$-quantile (in the lower tercile) of loan growth for all banks in the respective country and year, the value of 1 if above the 66.7\%-quantile (upper tercile), and the value of 0 if in between (mid tercile). Panel A tests $\mathrm{H} 1$ and explains the natural logarithm of the ratio of loan losses in $\mathrm{t}$ (LOGLL1), as defined above, by the lags 1-4 of loan growth (LG), as well as the lagged dependent variable. In Panel B (testing H2) and Panel C (testing H3), respectively, the absolute change from t-1 to t of the relative interest income $(\Delta \mathrm{RII})$, or the absolute change of the equity-to-total-assets ratio $(\triangle \mathrm{ETA})$ are explained by the contemporaneous loan growth rate (LG). In all panels, we control for bank-specific effects using the logarithm of total customer loans (LOGTCL) and indicator dummy variables for each bank specialization, as well as for macroeconomic effects with the GDP growth rate (GDP_GROW) or the inflation rate (INFLAT), the 10-year government bond yield (INT_LONG) and country dummies. P-values are calculated from Huber-White robust standard errors, controlling for clustering at individual banks. ${ }^{* *},{ }^{* *}, *$ indicate that coefficients are statistically significant at the $1 \%, 5 \%$, and $10 \%$-level. 